\title{
Workshop production of brooches with religious symbolism around the year 1100 in Denmark
}

\author{
Mette Højmark Søvsø $\varnothing^{1,3}$ and Christian Vrængmose Jensen² \\ 1 Sydvestjyske Museer, Tangevej 6B, 6760 Ribe, Denmark. \\ 2 (Author of the section 'The workshop in Aalborg'). Nordjyllands Historiske Museum, Algade 48, 9000 Aalborg, Denmark. \\ (christian.vraengmose@aalborg.dk) \\ ${ }^{3}$ Corresponding author (mhs@sydvestjyskemuseer.dk)
}

\begin{abstract}
Small brooches with Christian motifs from the period of C. AD 1050-1150 occur frequently amongst metal-detector finds in Denmark. Those known as Urnes brooches, bird-shaped brooches and circular animal brooches are especially common finds over most of the country. In order to understand what lies behind the distribution and significance of these brooches, the issues of where they were made and who was responsible for production are key questions. The large number of finds must reflect a serial form of production, but up to a few years ago secure evidence of any workshop has been almost effectively absent. Presented in this paper are two recent finds of workshops in which the manufacture of these types of brooches took place, in Ribe and Aalborg respectively. On the basis of the archaeological contexts of the workshops and the finds, it is proposed that this production is to be seen as primarily an urban phenomenon, with the Church as initiator and key agent, directed at a broad circle of customers. This may have been part of an evangelizing thrust with wider popular appeal in which these small but highly meaningful artefacts played an important symbolic role.
\end{abstract}

ARTICLE HISTORY

Received 18 August 2019; Accepted 20 February 2020

\section{KEYWORDS}

High medieval jewellery; Amulets; Christian symbolism; Christian mission; Bronzecasting; Craftsmanship

\section{Introduction}

The earliest centuries following the introduction of Christianity to Denmark are not rich in evidence in respect of costume and the use of dress-accessories. Metal-detector finds are a growing and primary source in this respect. The many finds show that brooches were part of the costume, and that in the period of c. AD 1050-1150 three types in particular stand out as widespread. These are those known as Urnes brooches (Bertelsen 1994; Westergren 1986), bird-shaped brooches (Pedersen 2001) and circular brooches with an animal motif of the Aalborg-group Type and Agnus Dei brooches (Bertelsen 1992; 1993).

The terminology which has been in use up to now in respect of the brooches can be imprecise and not very idiomatic. ${ }^{4}$ The name bird-shaped brooch is the least problematic in this regard, as the name is short and precisely reflects the design of the brooches rather than any specific stylistic features.

In the following, 'animal loop brooches' of the Urnes type will still be referred to as Urnes brooches, a term which continues regularly to be used in the literature (Christiansen 2017, 86; Gilså in press), and 'animal loop brooches' of the Aalborg[-group] type and the Agnus Dei type will generally be referred to as circular animal brooches.

Although the three brooch types are common finds on many metal-rich sites all over Denmark, almost none were until recently found in archaeological contexts. As a result of this, there are a number of unanswered questions regarding the production, use and meaning of these obviously common and widespread artefacts in the period c. $1050-1150$.

A few years ago, two new finds of workshops that were operative in the decades around 1100 were made in the course of archaeological investigations in Aalborg and in Ribe. At both sites, several of the brooch-types referred to above were produced. With the archaeological contextualization, a new insight can be gained into the production methods, the relation between the brooch-types and the meaning of their symbolism. The finds constitute an important breakthrough in respect of the background for the popularity and widespread 
distribution of the brooches. Questions, that cannot be answered on the basis of the detector finds alone.

Starting from the evidence of the workshop finds from Ribe and Aalborg and making use of a series of parallels amongst detector finds, the focus of this article is upon the following questions:

- Where did production take place?

- What group of customers was it directed at?

- Who was responsible for it?

- What was the basis of the distribution and popularity of the brooches?

\section{The brooches - current knowledge}

The Urnes brooches appear, despite their name, in the Ringerike and Urnes Styles or with Romanesque features, but the majority are in the Urnes Style (Bertelsen 1994; Gilså in press; Røstad 2012, 193). The bird-shaped brooches may contain elements of either the Ringerike or Urnes Styles but are mostly quite separate from the Scandinavian stylistic tradition (Pedersen 2001, 39). The circular animal brooches are found in both Urnes and Romanesque Styles (Bertelsen 1992). Altogether, the stylistic features of the brooches show that their centre of gravity lay in the period of the Urnes Style, c. 1050-1150.

The brooches are generally of modest size, typically with a maximum dimension of $2-3 \mathrm{~cm}$. They are provided with pin-fittings on the back, and often too with a loop or a hole for suspension of a chain or whatever. Their principal area of distribution is in present Denmark and to a lesser extent in Skåne in present Sweden (Hårdh 2010; Røstad 2012, 181). The intensive use of metal-detectors in Denmark consequent on the Danefæ legislation may be part of the reason for this. Before more intensive metal-detector activity began taking place in Denmark from around 1990, the number of finds from Sweden, Norway and Denmark were almost even (Gilså in press). It should be taken into consideration, when looking at the geographical distribution that intensive use of metal detector can change the picture drastically over short time (Feveile 2018).

The large number of detector finds which have been declared as Danefæ are curated by the $\mathrm{Na}$ - tional Museum, while the majority of the associated data are recorded at the local museums in accordance with the delivery of the finds. At the moment it is consequently impossible to produce any major data-pull which could provide an overview of the whole body of finds in respect of specific brooch-types and more precise find spots, and thus to use the Danish detector finds for regional or trans-regional studies. In a recent study of the Danish finds of Urnes brooches based on data from the National Museums collection some figures for the overall count has become available (Gilså in press). This study includes 850 finds of Urnes brooches (ibid), and mentions furthermore 348 bird brooches, and around 264 circular animal brooches of the Aalborg group (214) and the Agnus Dei type (around 50) (ibid). The number grows continuously. In DIME (the new, user-driven recording platform for detector finds) (Dobat et al. 2019) around 60 finds of circular animal brooches are registered from 2/1 2018-23/10 2019.5

The recent study of Urnes brooches (Gilså in press) has been very usefull as reference material in this paper, but many other examples are discovered via net-based detector fora, with the find places subsequently verified via the relevant local museums. Several museums have made more comprehensive information about finds from their areas available, while data from DIME have also been used.

When looking at the numbers of brooch finds from the period, they are remarkably high compared with other medieval artefact-types in the category of jewellery and dress-accessories. As an example, there are around 300 finds of pilgrim badges from the whole of Denmark, an artefact-type that is datable across several centuries from the $13^{\text {th }}$ century to the $16^{\text {th }}$. $^{6}$

The numbers and distribution of the brooches leaves us with questions about the background for their popularity, who the users were, and what the motives meant to the people at the time. The use of small amuletic brooches with animal designs rooted in religious ideas has its roots back in the Late Iron Age and Viking Period (e.g. Gräslund 2006; Pedersen 2014; Petersen 2005). In the course of the $11^{\text {th }}$ century new motifs and symbols came to influence the decoration of the brooches, but their structure with pin-fittings and a loop for attach- 
ments remained the same (Baastrup and Petersen 2008; Pedersen 2014). When it comes to interpreting the brooch motives, some of them are a bit harder to decode for us today than others. It has previously been suggested that the animal and snakes on the Urnes brooches depicts two animals in battle or a snake subjecting itself to the large animal (Lindahl 1983, 40), furthermore, Urnes brooches has been interpreted as emblematic royal tokens (Bertelsen 1994, 351, 358; Gotfredsen 2002, 41; Lindahl 1983, 40; Westergren 1986, 10-12), or media for social communication which expressed political and ethnic affiliation: the latter especially because of their significant geographical distribution within the territory of Denmark (Røstad 2012). A more recent explication of the design of the Urnes brooches, an animal encoiled by a snake, is that this is to be seen as an image of God the Father and the Holy Spirit in intimate symbiosis and not as two beasts fighting one another (Wood 2014). The designs can therefore be regarded as purely Christian rather than political propaganda. According to this interpretation, the Urnes brooches were presumably more than anything else attributed with intrinsic powers and were not purely symbols intended to signal something externally. They thus embody continuity in use and significance: an old and well-known amulet brooch-type in a new dress (Andersen 2015, 52-3; Baastrup and Petersen 2008; Pedersen 2001, 52-3; 2004, 72; Pedersen 2014, 221; Petersen 2005).

Amongst detector finds from the Early Viking Period, locally manufactured cross-shaped brooches, known as Råhede brooches, occur; these are have been suggested to be tokens of baptism, distributed in connection with the Christian mission (Feveile 2011). In the late Viking Age and early Christian period in Denmark the imported Carolingian-Ottonian enamel brooches could have had the same function (Baastrup 2014, 105-10; Beck, Christiansen and Henriksen in press, 32-3, 57; Roslund 2010). With the marked ingress of brooches with Christian symbolism from the decades around the year 1100 the situation appears for the first time to have involved an extensive local production of amulets of Christian significance.

In the pre-Christian period, brooches were most often female jewellery, while from the early Christian period we have no grave finds, nor written or pictorial sources, showing by whom the brooches were used or how, or anything concerning their role and importance at the time. ${ }^{7}$ In this respect, the surviving objects are themselves a primary source. The questions are, whether the continuity that can be seen in the construction of the brooches, pin-fittings combined with a loop, is an expression of continuity in use, and whether the brooches are still female jewellery or were worn by both sexes (Bertelsen 1994, 350-1; Røstad 2012, $200,203)$. In the Christian context there seems to be a tradition for other small brooches with religious symbolism - such as, for instance, the previously-mentioned enamel brooches - to have been worn by both men and women (Baastrup 2007, $6)$, just as several other types of medieval jewellery, such as finger rings and later ring brooches too, were common to both sexes.

\section{Background: Workshop finds and mo- dels of organization}

Medieval jewellers' workshops, not least from the early Christian period, have hitherto been rare in the extreme in Denmark. During excavations in Viborg, a workshop of the first decades of the $11^{\text {th }}$ century has been found, at which operation appears to have been seasonal and to have involved the bronzecaster and the silversmith on varying occasions (Jouttijärvi et al. 2005; Thomsen 2005). The only certain evidence from medieval Denmark of the production of the brooches listed above until just a few years ago was a workshop found in Lund, the so-called 'Urnes workshop'. Urnes brooches were certainly manufactured here in the period of c. 1100-1150 while models for circular animal brooches and bird-shaped brooches also occur amongst the finds from the town (e.g. Bergman and Billberg 1976; Bertelsen 2002b cat. nos. 44-45; Blomqvist 1947; Carelli 2012, 86877; Cinthio 1999; Salminen and Hervén 2001; Stenholm 1976). Outside medieval Denmark, a mould for casting of Urnes brooches occur among the findmaterial from Sigtuna. ${ }^{8}$

The brooches were cast in clay moulds (Bergman and Billberg 1976,207) which had been built up either over a solid model (Lønborg 1998, 71) or using a wax model (Söderberg 2018). Both meth- 
ods had their roots back in the Late Iron Age and Viking Period and are well attested archaeologically in several of the Viking-period emporia, including Ribe and Kaupang (e.g. Feveile and Jensen 2006, 60; Madsen 1984, 91-5; Pedersen 2016). The understanding has been that the use of solid models was better suited to serial production than wax models were (Lønborg 1994; Madsen 1984, 91) as the latter could be used only once while a solid model could be re-used many times over. Experimental studies, however, indicates that the opposite can in fact be the case (Hedegaard 1992; Söderberg 2018,7). The theory, that the slim loops of the Urnes brooches would not be suitable for melted wax to pass through, has never been experimentially tested yet (Lønborg 1994, 372). Another possibility is, that both methods have been used simultaneously. As shown in Gilsås study on the Urnes brooches, the majority of the brooches are made of copper-alloy (Gilså in press). Judging from previous publications (Bertelsen 1992, 1994; Pedersen 2001) and data from DIME and detector fora, this seem to be the case for the bird brooches and the circular animal brooches as well.

For the specialist crafts, including the casting of copper-alloy jewellery, both mobility and close associations with a powerful elite, trading centres and urban contexts are considered to have been fundamental prerequisites (Calmer 2003, 359; Salminen and Hervén 2001). With regard to bronzecasting in the Iron Age and the Viking Period a series of models to represent the organization of the craft have been elaborated: administered urban economy casting; merchant and raw material casting; professional super-regional casting; court casting; socially governed casting; and domestic casting (Hedegaard 1992; Pedersen 2016, 35; Söderberg 2004). Several of these modes of craft-organization existed side-by-side for a long time, but in the course of the Middle Ages, with the growth of multiple urban environments, the specialist artisans acquired a more permanent customer and work base and came to constitute a core of the development and economy of the towns (Callmer 2003). In Lund, those who practised metalworking are consequently viewed from around the year 1100 as an organized workforce. They were nevertheless always subject to the power-wielding elite that owned the land on which the workshop activity took place.
Over time the craftsfolk appear to achieve a greater degree of economic independence, reflected, amongst other ways, in more direct contact with the customers (Carelli 2012, 76, 86; Salminen and Hervén 2001, 268).

The geographical distribution of specific varieties and finds of lead models and miscast objects is often regarded as evidence of the individual stamp of workshops and their presence, locally or regionally (Bertelsen 1992, 1994; Christiansen 2017, 87; Lønborg 1994; Pedersen 2001, 2010). Brooches manufactured in urban contexts (administered urban economy casting), with the discovery in Lund in mind, may have been the source and inspiration for local production (domestic casting) and/or itinerant craftsmen who copied items of jewellery on demand (professional super-regional casting). The inconsistent artistic quality of the brooches has been interpreted as a reflex of more or less professional artisans' skills, the work of various local workshops, or degeneration in the direction of the more stylized and imprecise over time (Christiansen 2017, 86-7, 91-2; Lønborg 1994, 371; Pedersen 2010; Ramskou 1957, 199-200; Westergren 1986). If the method of production included the use of a solid model it would mean that a brooch could be copied quite readily. Together with the fact that artefacts can be transported to another location in order to be sold, and may be lost at many locations other than where they were manufactured, more certain evidence of workshop production would be production waste such as moulds, metaldrops and/or miscast artefacts.

\section{The workshop in Ribe}

\section{The workshop building and its archaeo- logical context}

In the course of excavations south of Ribe Cathedral in 2011-12, the remains of a bronzecaster's workshop were excavated (Figure 1). The settlement phase to which the workshop activity pertains is dated c. AD 1050-1150. The area was previously part of the churchyard, and subsequently a House of Canons was built on the site. During the excavation of the settlement the remains of several 


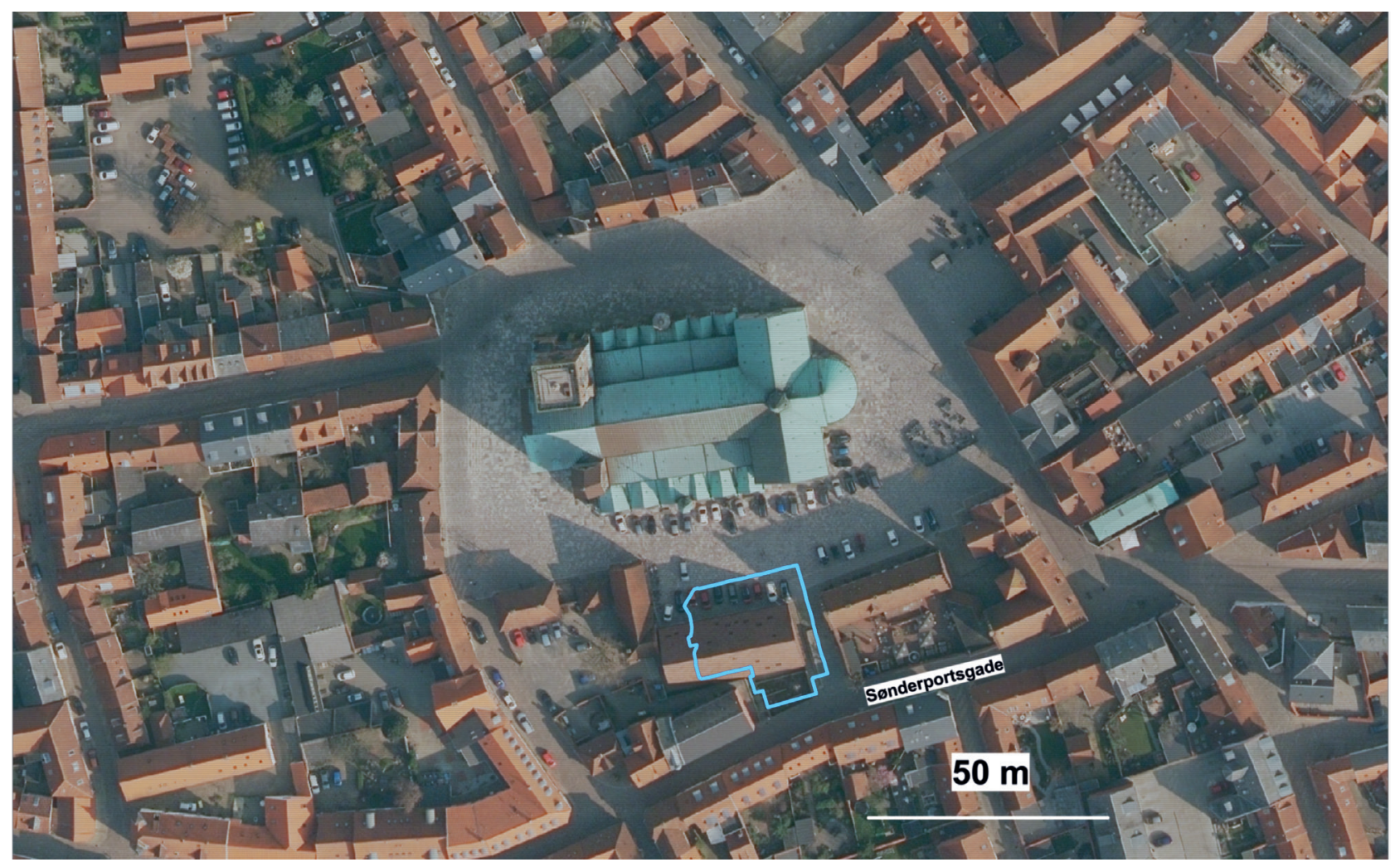

Figure 1. (a) Aerial photograph with the area of excavation marked. Photo/illustration: Danish Geodata Agency/Morten Søvsø.

timber buildings were found which had, however, been extensively disturbed by later activities (Excavation report: ASR 13).

Alongside the street line to the south (present Sønderportsgade: 'South Gate Street'), the remains of a stave-built structure with curved walls raised in 1077 were found. To the north this plot was bounded by a wooden fence in a foundation trench. In the north-eastern quadrant the remains of a small wooden building were excavated. This building is inferred to have been rectangular, and about $4.5 \mathrm{~m}$ wide. In its north-eastern corner was found a deep sequence composed of a large number of thin clay and dirt layers with a high level of admixed ash, and a round hearth some $0.6 \mathrm{~m}$ in diameter consisting of both clay and ash layers (Figure 2). Both the floor and the fireplace contained large quantities of production waste in the form of green staining, lumps of copper alloy, and clay crucible- and mould-fragments. Amongst the finds were numerous fragments of clay moulds for casting of different brooch types. Finds of crucible sherds and mould-fragments in the floor layer of the bow-sided building indicate that it was contemporary with the workshop. The workshop layers were cut by a number of pits at the

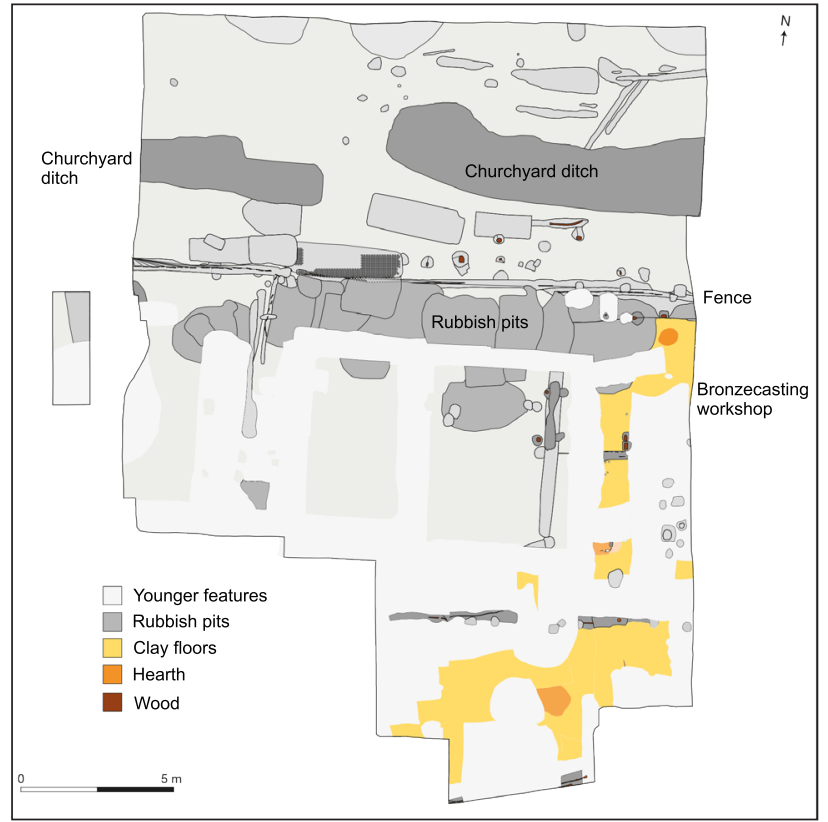

Figure 1. (b) The settlement phase with the remains of a workshop. Photo/illustration: Danish Geodata Agency/Morten Søvsø.

northern end of the plot that had been dug before the canonical cloister was built around 1150. On this basis, the functional period of the workshop can be narrowed to post-AD 1077, and on into the first decades of the $12^{\text {th }}$ century. 


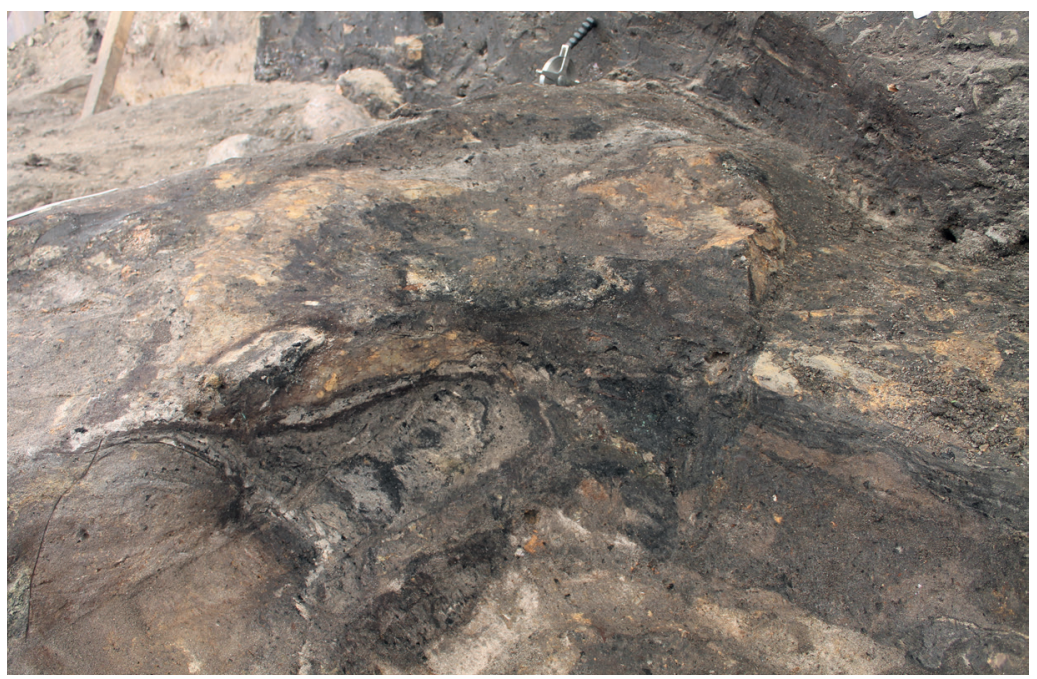

\begin{tabular}{|l|l|}
\hline & Totals \\
\hline Mould-fragments & 3628 \\
\hline Crucibles and crucible sherds & 2570 \\
\hline Molten copper-ally drops & 462 \\
\hline Brooches & 23 \\
\hline Honestones (from primary contexts) & 21 \\
\hline Touchstones & 2 \\
\hline
\end{tabular}

Figure 2. Section through the hearth in the workshop. Photo: SJM.

Table 1. The finds quantified.

\section{The finds}

Water-sieving increased the quantity of finds collected, especially in respect of production waste from the workshop (Table 1). Some of the finds are from the floor layer and the hearth in the workshop building but the distribution otherwise shows that the waste must have largely been gathered up and cast out over the plot around the workshop building, or buried in waste pits. Clay mould-fragments, crucible sherds and brooches also occur in later waste pits, building layers and other features subsequently cut into the area. The highest proportion of finds were from the fill of the churchyard ditch immediately to the north of the plot, including several large mould-fragments and eight complete crucibles (Figure 3a). The quantity of finds and the good quality of preservation indicate that these were deposited directly from the workshop.

\section{Technical details of the finds}

The clay moulds occur as fragments of half-form part-moulds with the impression of either the face or the reverse of the object to be cast. Amongst the fragments there are a number of larger pieces, but no complete part-moulds (Figure 4). The degree of fragmentation could indicate that the moulds were broken after casting in order to remove the finished object, but it cannot be determined for certain that the moulds could have been or indeed ever were re-used.

\section{Two-part moulds}

By far the majority of the moulds had been two-part moulds with an upper and a lower half. Preforms for pin-fitting in the form of two prongs were cast in with the brooch itself (e.g. Figure 4a, 16a, 19b). The prongs were subsequently drilled through and filed to shape so that the pin could be attached. The correct position of the two mould halves in relation to each other was secured in the process of casting by keys- and keyholes which were located at the edge of the mould (Figure 5, 17f) (Feveile and Jensen 2006, 159; Madsen 1984, 93). The gate could have been formed with the aid of a wooden model (Lønborg $1998,71)$. The inlet gate was an integral part of the mould. The molten metal was poured in through this into the cavity of the mould (Figure 6a). 

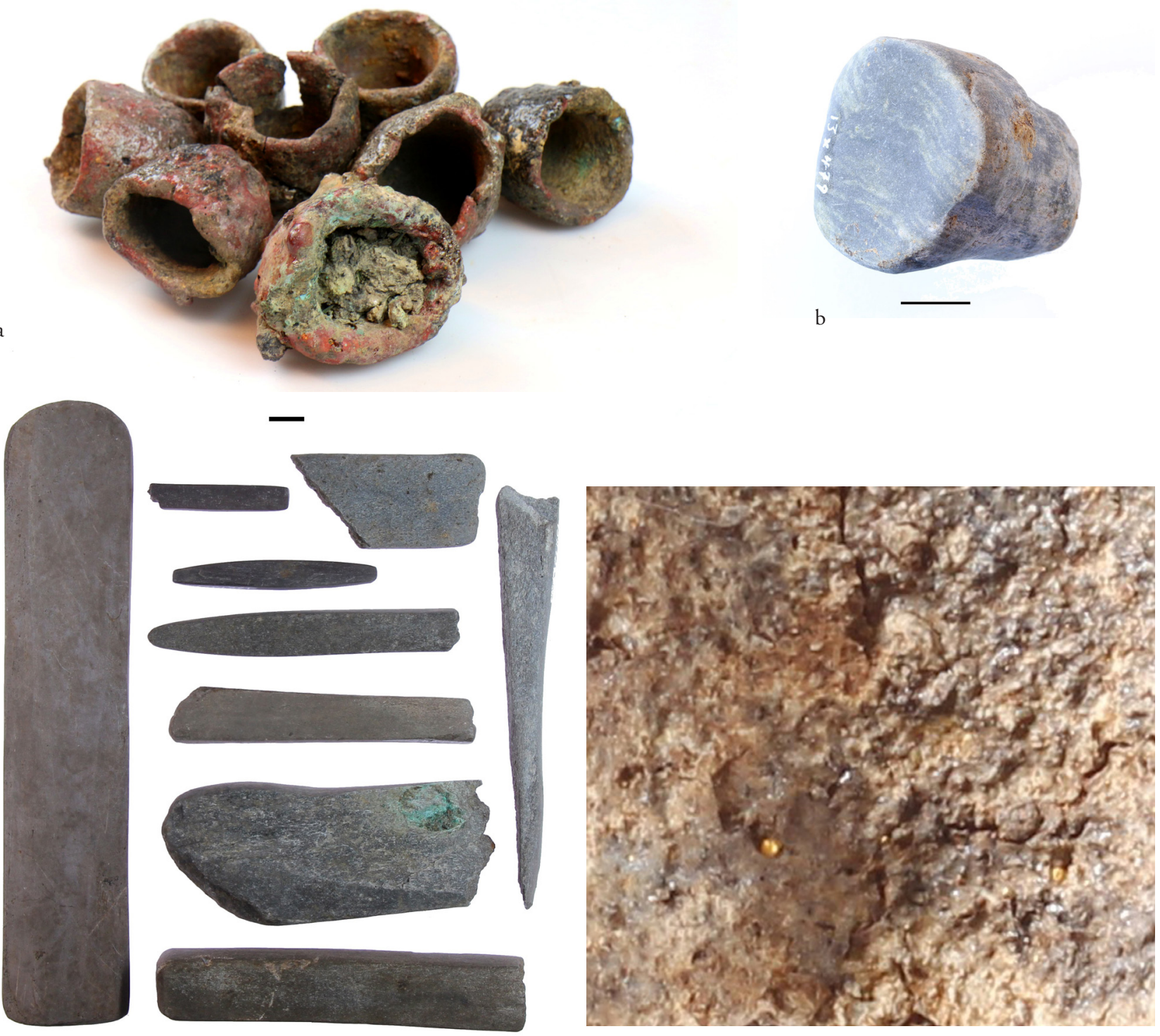

c

$\mathrm{d}$

Figure 3. Equipment and tools. (a) Crucibles ASR $13 \times 1065, x 1143, x 1314$. Without scale. (b) Possible touchstone ASR 13x479. 1:1. c) A selection of honestones ASR 13x406, x491, x742, x1244, x1329, x1356, x3552, x3535, x3563. 1:2

(d) the inside of a crucible sherd with small golden drops. ASR 13x1420. Without scale. Photo: SJM/Henrik B. Christiansen (HBC).
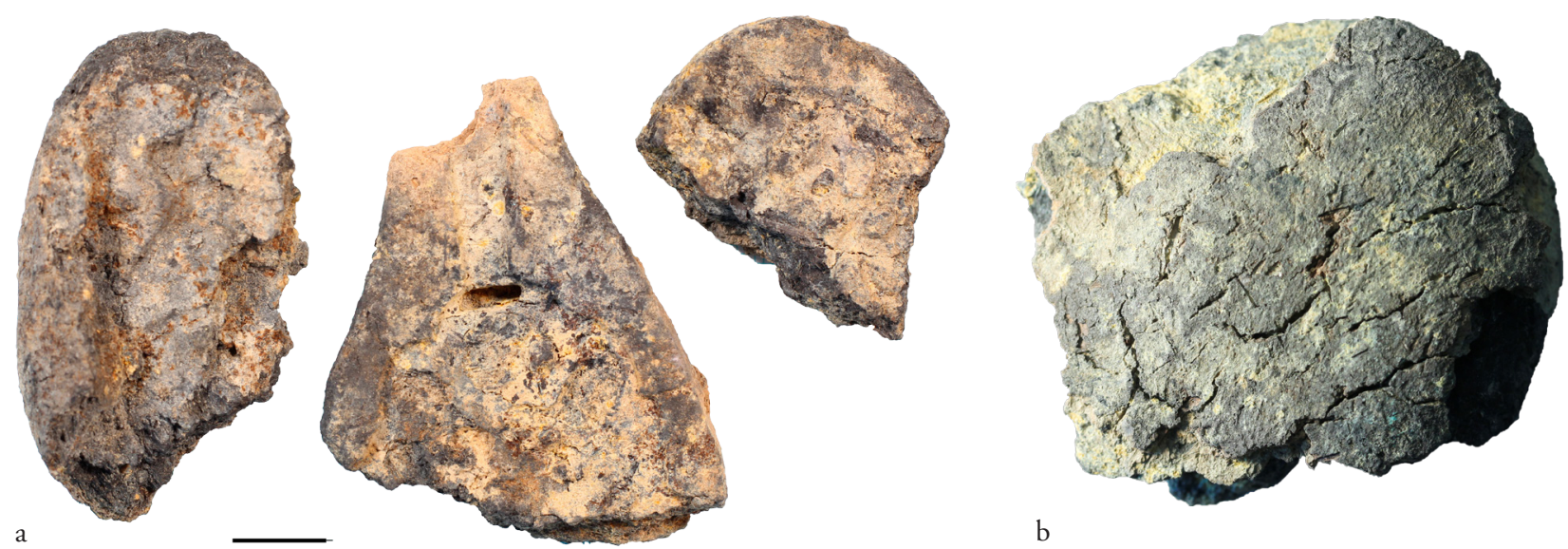

Figure 4. Examples of larger mould-fragments. (a) The central piece has a channel (sprue) leading to the reverse of a brooch with a pin-fitting ASR 13×3162 (3 parts). (b) The reverse of a larger fragment ASR 13×3564. 1:1. Photo: SJM/HBC. 


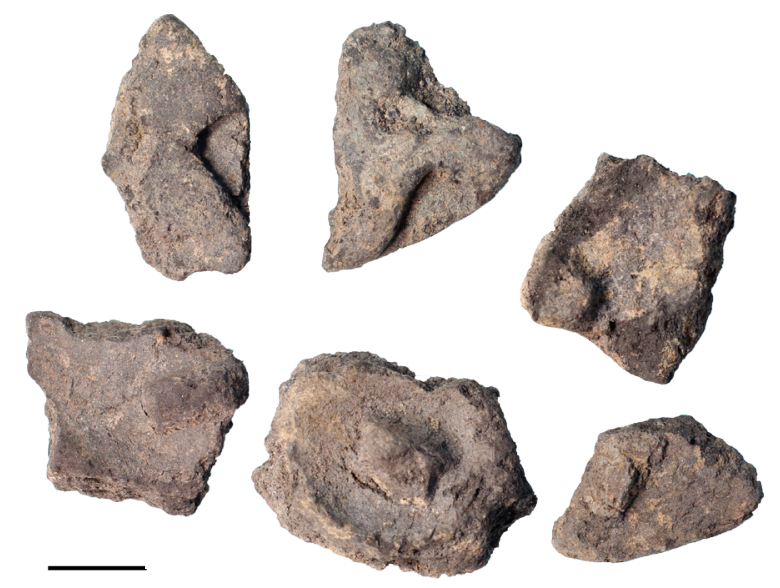

Figure 5. Mould-fragments with keys and keyholes. ASR 13x3530, x3482, x3552. 1:1. Photo: SJM/HBC.

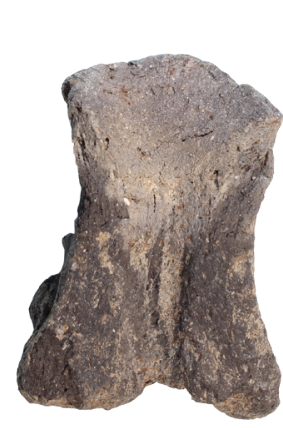

a

Figure 6. (a) Fragment with a sprue channel and gate. ASR 13×3469. (b) Fragment with three sprues for three brooches. ASR 13x3126. 1:1. Photo: SJM/HBC.

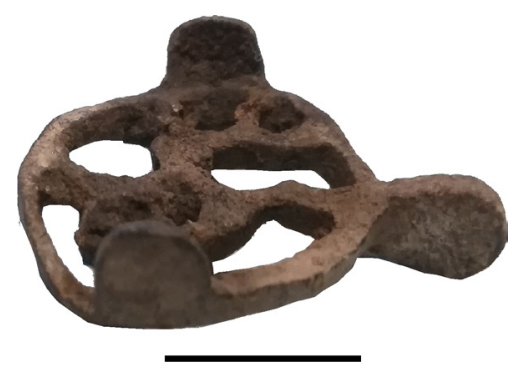

Figure 7. Lead-model for a circular brooch with animal design. ASR 13x4255. 2:1 Photo: SJM/HBC.

\section{Double- and triple moulds}

In a number of cases, the bronzecaster was working with moulds for two objects at a time, presumably to save time and resources. What were cast in a single mould could be examples of the same broochtype or different types (e.g. Figure $13 \mathrm{~m}, \mathrm{p}, \mathrm{r}, \mathrm{s}, 15 \mathrm{a}$, $17 \mathrm{e})$. There is a single case of a mould with a sprue that branches into cavities for three separate objects (Figure 6b).

\section{The models}

Among the workshop findmaterial is a lead-model for a circular animal brooch (Figure 7). This, and the use of two part moulds, used in order to remove the model after the mould had dried, and the presence of keys- and keyholes in order to hold the two half-moulds together in the right position during casting (Figure 5, 16a), are proof of the use of solid models in the workshop. However, it is a possibility, that both solid models and waxmodels could have been in use in the workshop. Anders Söderberg has shown how one can advantageously make use of wax models in the serial production of Urnes brooches in clay moulds (Söderberg 2018). One feature which is visible on some of the large quantity of detector-found brooches is evidence of the trimming of the openwork areas on the reverse of the brooch. This modification is assumed to have been carried out in a soft wax model and not on a finished cast metal brooch (Söderberg 2018, 6, figure 16, 20). Such marks can also be seen on some of the brooches that have been found in the Ribe area (Figure 12b, reverse). Future microscopic analyses of the surfaces of the moulds, however, together with casting experiments, may be able to shed light upon this (Söderberg 2018, 5).

\section{Miscasts and discarded brooches}

The small quantity of metal that was required for casting cooled down at lightning speed and it was thus easy for the casting to fail (Lønborg 1994, 373). One mould had collapsed during casting, perhaps because the clay had not been sufficiently fired; another mould's sprue is full of metal (ASR $13 \times 3537, \times 3564)$. For the casting of bird-shaped brooches, the sprue always led to the vertical end of the fan-shaped tail, and in several cases discarded or lost specimens show that there is still some casting flash from the sprue in situ as an extension of the tail (e.g. Figure 13a-c). In other cases the entire bird's body has gone awry during casting (Figure 13f, g). From the layers in and around the workshop a quantity of honestones have been found which could have been used for finishing work on the cast brooches, removing casting flash and excess metal (Figure 3c). 


\section{Open moulds}

Eleven mould-fragments stand apart through consisting of just a one-part oval mould (Figure 8a). The fragments have a substantial rectangular notch across the curvature of the oval, probably for a spike to hold the mould firmly during casting. The liquid metal must have been poured directly into the cavity, which is cross-shaped in all cases.

\section{The metals}

The metal alloys which were used for casting in this workshop have left green staining on the workshop floor and the fireplace layers, on crucibles and mould-fragments, and in the form of droplets. The discarded or lost brooches from the excavations are also copper-alloy. The conditions for the preservation of metals in the culture layers of Ribe are poor on the whole, and metal remains and objects in the finds from the bronzecasting workshop are generally highly corroded, with surface degradation. As yet, no systematic analysis of the metals from the workshop has been carried out, but XRF-analyses of the surface of four mould-fragments have revealed traces of copper, zinc and lead. Two crucibles contained traces of copper while the contents of two brooches were, respectively, copper/tin and copper. ${ }^{9}$ Some of the brooches were therefore apparently of a brass-like alloy and were originally a shiny gold colour. An Urnes brooch that was found during the excavation of a well in a settlement south of Ribe was probably manufactured in this workshop (see below). This brooch is in good condition and it gives an impression of the gold-coloured surface the now corroded brooches may have had (Figure 10a). This may have rendered the use of coatings unnecessary, but the discovery of just one crucible sherd with a couple of drops of gold (Figure 3d) and a touchstone (Figure 3b), nevertheless shows that the workshop must have worked with this precious metal to some extent, possibly for gilding.

\section{The products of the workshop}

Amongst the whole collection of mould-fragments there are a number with no impressions, or with

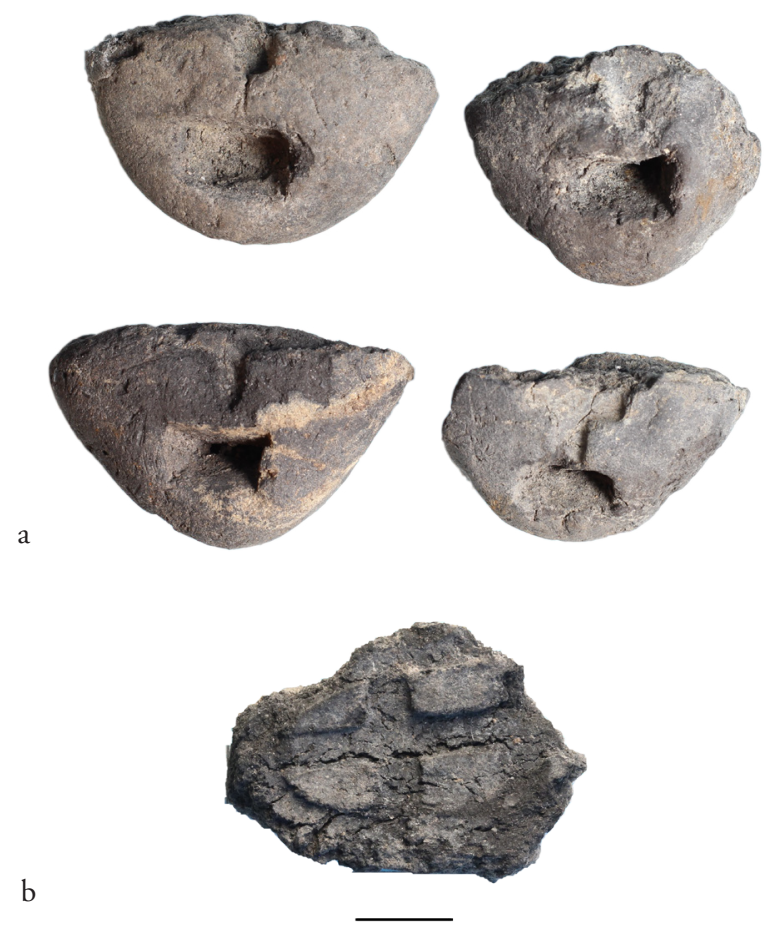

Figure 8. (a) Fragments of open one-part moulds for casting cross-shaped objects ASR 13x3495, x3467, x3534, $x 3474$. (b) Fragment of a two-part mound for the casting of the same type of object ASR 13×3492. 1:1. Photo: SJM/ $\mathrm{HBC}$.

such limited impression evidence that they cannot be identified to brooch-type. From the 1,774 fragments with impressions, 497 can be identified to type. It is important to bear in mind that whole or larger impressions of, for instance, the small and compact bird-shaped brooches (Figure 13) will have stood a better chance of surviving because of their size than impressions on moulds for large Urnes brooches that would have been likely to suffer a higher degree of fragmentation (Figure 10) and so be represented in a larger number of fragments. The majority of the fragments do indeed have the impression of looped ribbon work of the Urnes Style without the exact appearance of the brooch being determinable. The repertoire of products that is presented below therefore probably constitutes only part of the total range of brooches, with possibly other artefact-types to be included as well. In order to reconstruct the repertoire, mould-impressions and miscast or discarded brooches from the workshop context have been compared, along with other archaeological finds from Ribe and from other metal-rich sites in the hinterland of the town (Table 2; Figure 9). 


\begin{tabular}{|c|c|c|c|c|c|c|c|c|c|c|}
\hline & Urnes- & Bird- & $\begin{array}{l}\text { Circular } \\
\text { frame } \\
\text { with } \\
\text { animal } \\
\text { design }\end{array}$ & $\begin{array}{l}\text { Circular } \\
\text { frame, } \\
\text { inidenti- } \\
\text { fiable }\end{array}$ & $\begin{array}{c}\text { Palmette } \\
\text { brooch }\end{array}$ & $\begin{array}{c}\text { Double } \\
\text { cross }\end{array}$ & $\begin{array}{l}\text { Double } \\
\text { moulds } \\
\text { included }\end{array}$ & $\begin{array}{l}\text { Uniden- } \\
\text { tifiable } \\
\text { impres- } \\
\text { sions }\end{array}$ & $\begin{array}{l}\text { No im- } \\
\text { pression }\end{array}$ & Total \\
\hline $\begin{array}{l}\text { Mould-im- } \\
\text { pressions }\end{array}$ & 347 & 127 & 9 & 47 & 2 & 12 & 40 & 1230 & 1854 & 3628 \\
\hline $\begin{array}{l}\text { Miscast/ } \\
\text { discarded } \\
\text { brooches }\end{array}$ & 4 & 7 & 4 & & 1 & 2 & & & & 18 \\
\hline
\end{tabular}

Table 2. The workshop repertoires.

\section{Urnes brooches}

The design of Urnes brooches is a quadruped animal surrounded by looped ribbons. The loops may extrude from the beast itself or be separate animals (Bertelsen 1994, 347). In many cases the design is so stylized that it can be difficult to distinguish the distinct components of the design. Larger loopholes at the bottom of the brooch motive, or next to the animals feet presumably provided a loop for the suspension of other ornaments, or for a chain or lace to be attached.

There are 347 mould-impressions with segments of zoomorphic loops from Urnes brooches amongst the workshop finds. On the basis of this assemblage and finds of brooches, the following four types may be distinguished as one range of the repertoire of the workshop.

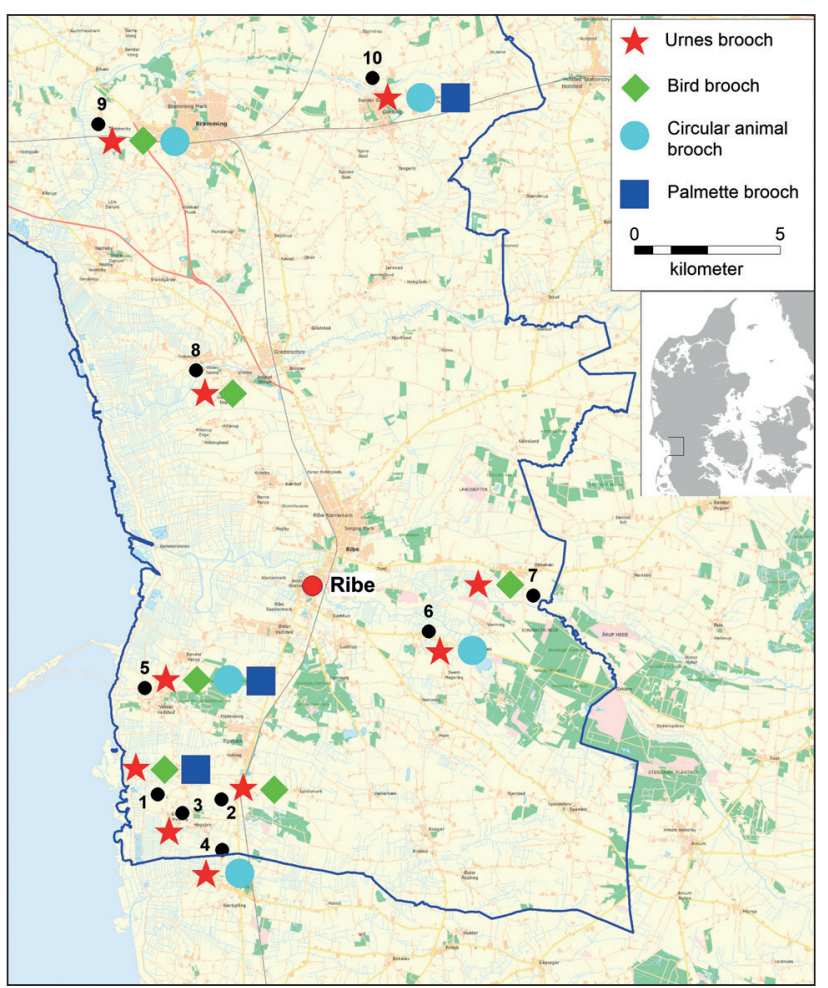

\section{Type 1}

This type depicts an elegant, slim animal surrounded by looped ribbons or snakes. The animal has a pointed oval eye, a small ear, a curled snout and curl decoration at the shoulder. One of the loops below the animal were probably used for fastening of an eye (as on figure 26e). It is the workshop's largest and most elegant brooch design. Type 1 is represented in the workshop material by one miscast fragment (Figure 10e) and one mould-impression (Figure 10g). Complete examples on this type has been found during excavations of settlements in the Ribe area. One was found at the base of a well that is dendro-dated to c. AD 1100 (Figure 10a) and the second from the wall trench of a building (Figure 10b) (Jensen 1991, 38; Pedersen 2010, 209). Three other finds, two found by metaldetecting and one found during an excavation in Ribe, are respectively of the beast's head (Figure 10c), the lower part of the beast's neck/back with looped decoration (Figure 10d), and most of a brooch apart from the head (Figure 10f) (Kristensen 1999, 143). On the first of these the surface is covered in minute pits, possibly a casting error. The brooch nonetheless has a pin-fitting and therefore was used despite its blemish.

\section{Type 2}

This type has three conspicuous claws on the forelegs and a small crest or ear on the head. Between

Figure 9. Finds of the workshop products from detector sites recorded at Museums of Southwest Jutland. (1) Gl. Hviding ASR 440, 1265, 1375, 1689. (2) Råhede ASR 872, (3) Høgsbrogård ASR 2321, (4) Vivegrøft ASR 2344, (5) Okholm SJM 154. (6) Seem kirke ASR 1021, (7) Obbekær SJM 740. (8) Vilslev Spang ASR 491. (9) Toftegård/Tømmerby ASR 1995, SJM 257. (10) Gørding kirke SJM 679. For specific finds from each location, se figs. 10-17, 19. Map: Claus Feveile. 


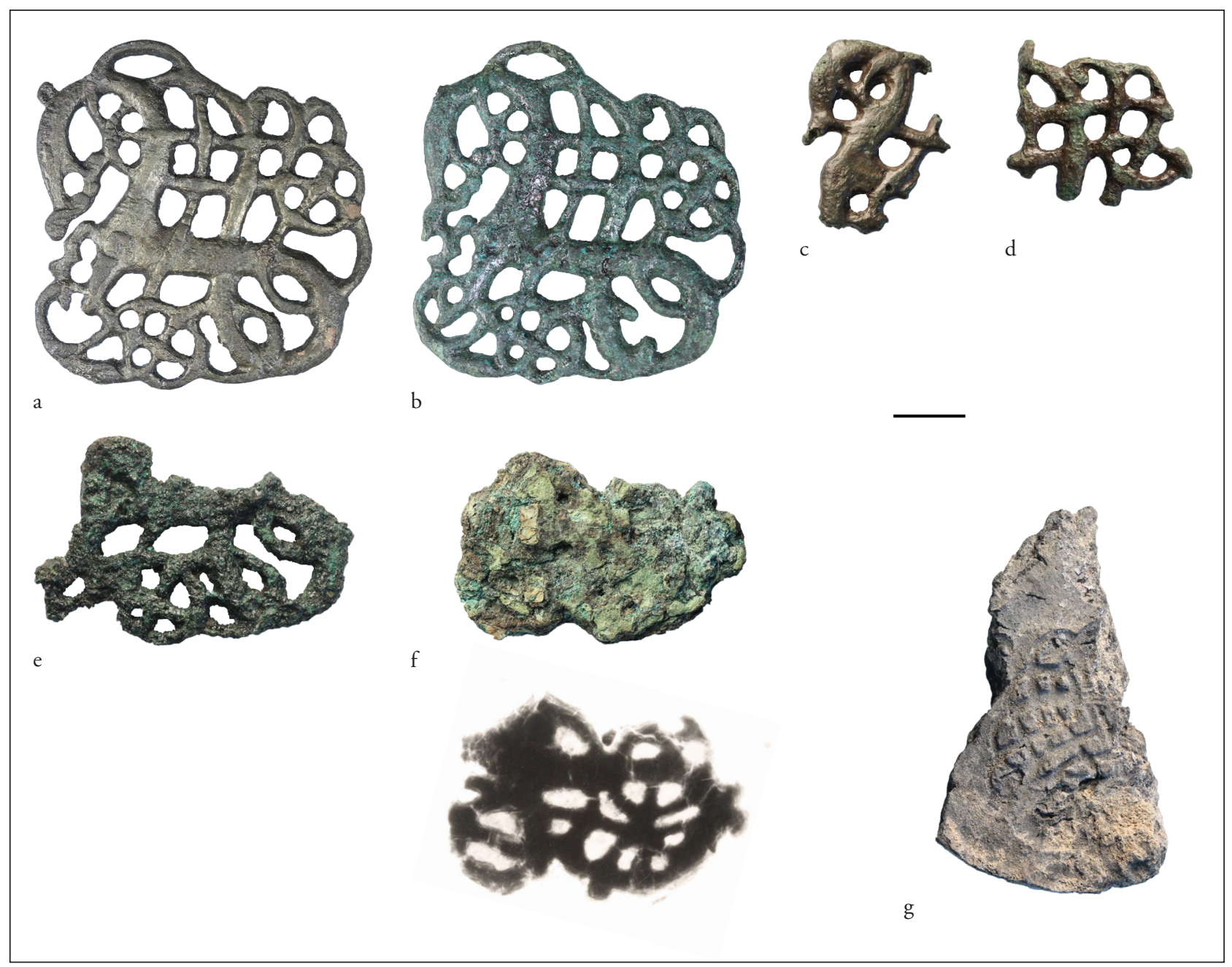

Figure 10. Urnes brooches, Type 1. (a) ASR 440x528. (b) ASR 491x21. (c) ASR 872x148. (d) ASR 872x52. (e) ASR 13x289. (f) ASR 565x279 (photo+X-ray). (g) ASR 13x3129. 1:1. Photo: SJM/HBC.

the claws a small hole is found which probably served as the loop. On well-preserved specimens there is marking in the form of transverse lines at the transition from the chest to the foreleg of the beast (Figure 11a, b). A miscast brooch from the workshop and six mould fragments are evidence for casting of brooches of this type (Figure 11h-l). The type is also known from a number of metal-rich sites (Figure 11a-f) and as an archaeological find from an excavation in the western part of Ribe (Figure $11 \mathrm{~g}$ ). They are all made of copper-alloy.

\section{Type 3}

The design on this type is an animal body with a beak-like mouth surrounded by looped decoration. The eye is a pointed oval. There is a single specimen from the workshop layer (Figure 12a) and the type is also known from metal-rich sites of the hinterland (Figure 12b-d).

\section{Type 4}

This brooch type depicts an winged, dragonlike animal looking over its back, surrounded by snakeloops. The animal has a small ear and an open mouth with a curled snout. On parallels a pointed eye and curl decoration at the shoulder can be seen. ${ }^{10}$ The snake and the animals heads are joined (in a kiss?) over the animals back. The design has stylistic elements from the Urnes- as well as Romanesque style. This type is only represented by a single miscast example from the workshop layers (Figure 12e).

\section{Bird-shaped brooches}

The workshop assemblage included 127 mould-fragments from the casting of bird-shaped brooches. Three distinct sub-types can be distinguished amongst these. All of the bird-shaped brooches have a hole formed between the claws 


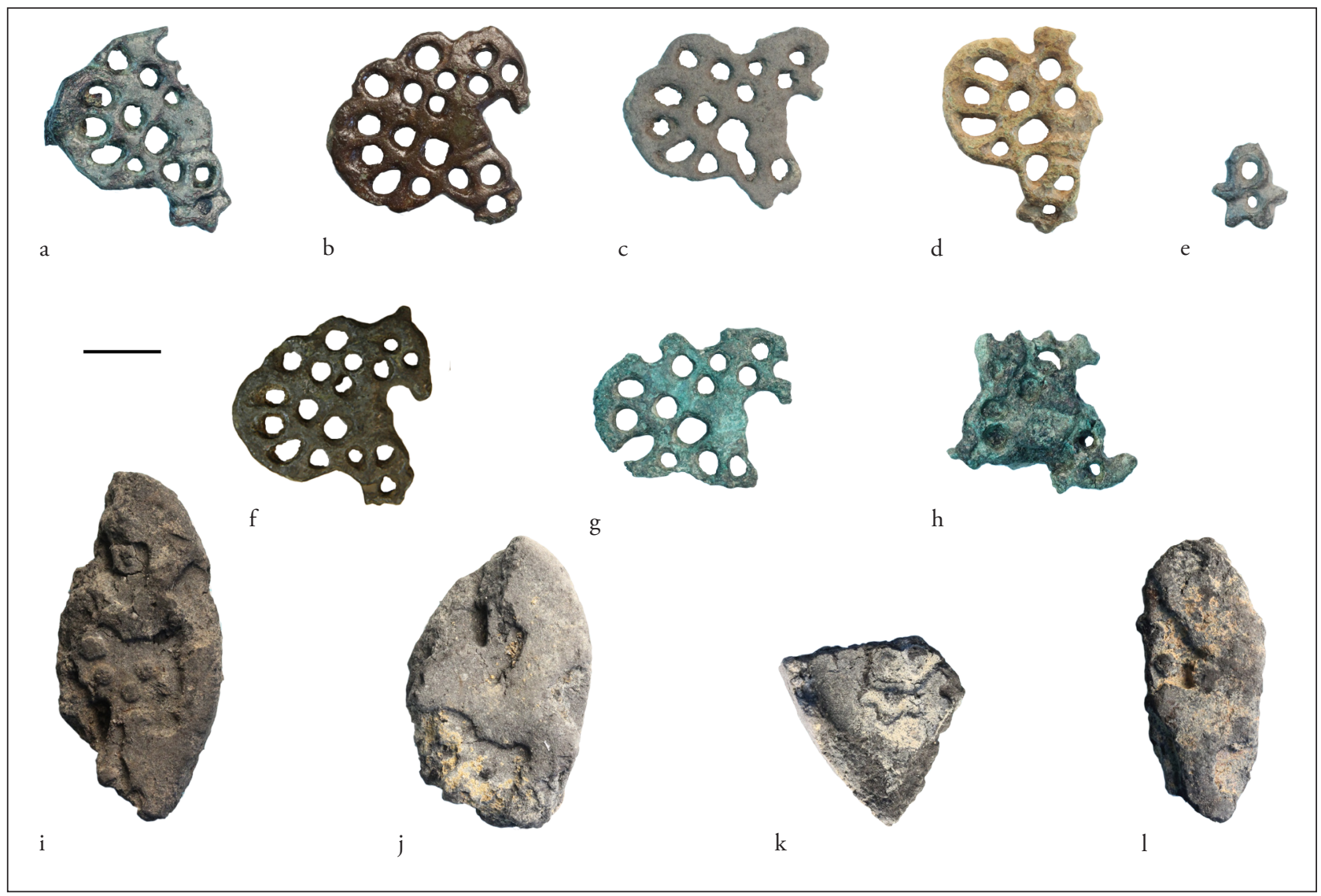

Figure 11. Urnes brooches, Type 2. (a) ASR 491x502. (b) ASR 1021x23. (c) ASR 1375x140, (d) SJM 740x23. (e) ASR 1689x22. (f) SJM 257x1. (g) ASR 11x3072. (h) ASR 13x3170. (i) ASR 13x3534. (j-l) ASR 13x3129. 1:2. Photo: SJM/HBC.

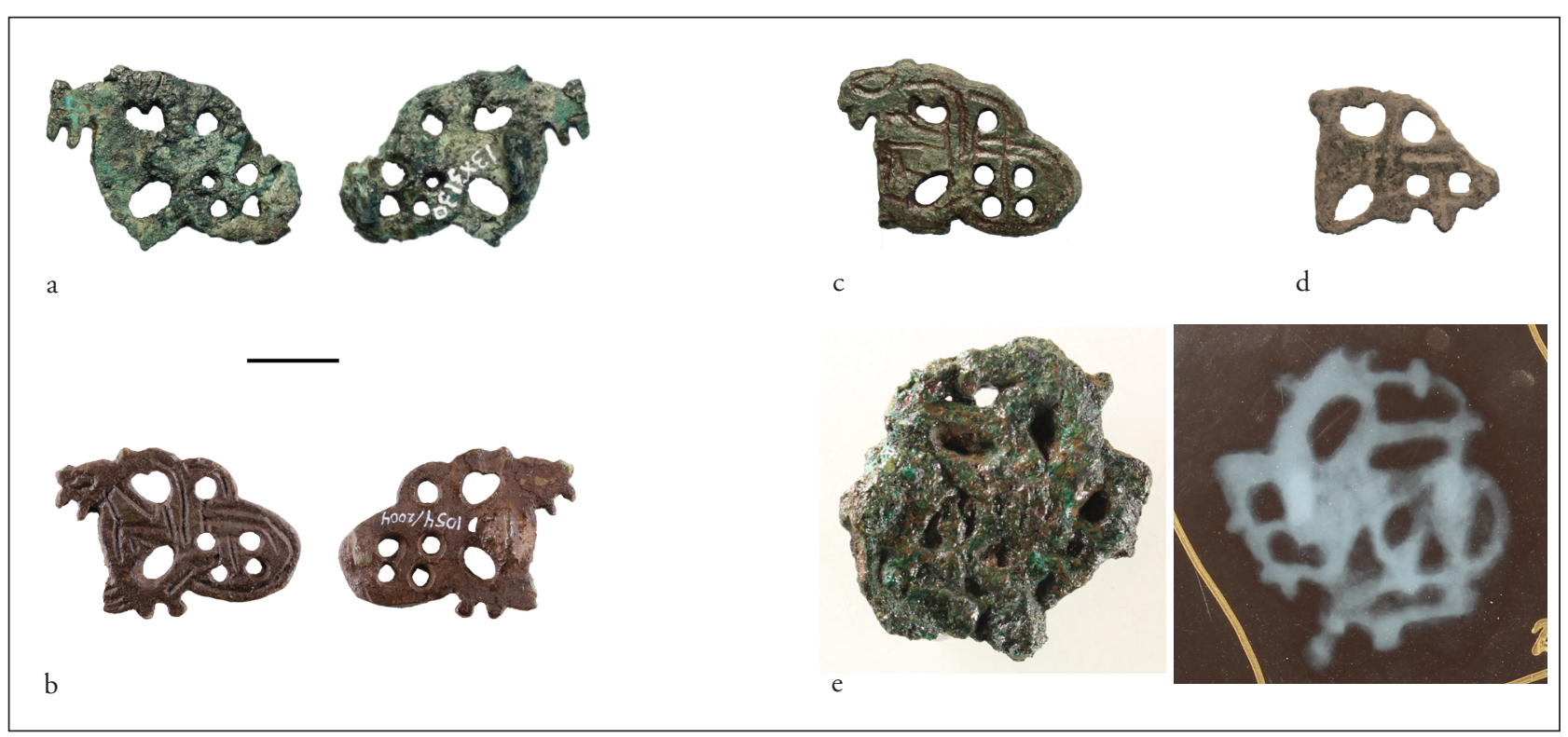

Figure 12. Urnes brooches, Type 3 (a-d) Type 4 (e). (a) ASR $13 \times 3130$ front and back. (b) ASR 1265x25 front and back. (c) ASR 872x70. (d) ASR 2321x239. (e) ASR 13x260 (photo+X-ray). 1:1. Photo: SJM/HBC.

which presumably provided a loop for the suspension of other ornaments, or for a chain or lace to be attached.
Type 1

The birds of this type have a small crest and stand on two legs with strong claws, between which there is a loop hole. They have a fan-shaped tail with 


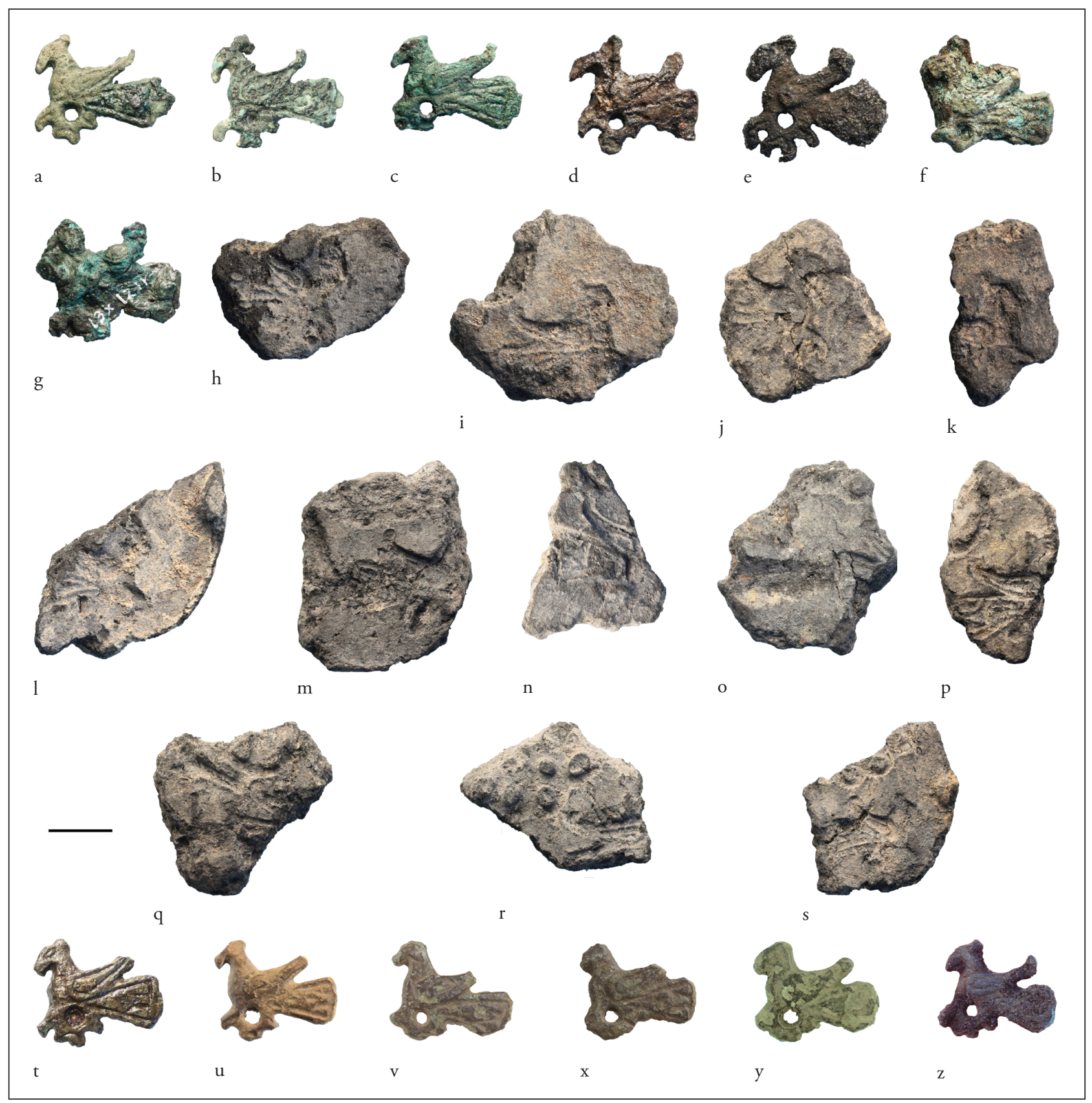

Figure 13. Bird-shaped brooches, Type 1. (a) ASR 13x479. (b) x3132. (c) x3036. (d) x1130. (e) x1273. (f) x512. (g) x1211. Mould-impressions: (h) x3492. (i) x3537. (j) x3552. (k) x3552. (l) x3129. (m) x3492. (n) x3492. (o) x3129. (p) x3495. (q) x3492. (r) x3492. (s) x3492. 1:1. Detector finds: (t) ASR 1689x83. (u) SJM 740x22 (v) SJM $257 \times 107$ (x) 115 (y) ASR $872 \times 351$ (z). HAM 5613x53. Photo, a-y: SJM/HBC. z: Poul Nørgaard Pedersen.

clearly marked feathers and a raised, slightly upturned wing with a small curl at the end. Where the demarcation of the eye survives it is pointed oval. There are 50 definite mould-impressions and seven brooches from the workshop layers. Amongst the mould-impressions, five are from double moulds in which bird-shaped brooches of Type 1 were cast along with an Urnes brooch (Figure 13q-s), and three were cast along with an openwork circular brooch (Figure 13p). This type is also known amongst detector finds from the hinterland of Ribe (Figure 13t-z).

\section{Type 2}

The wings of the bird of this type are raised and curve gently down towards the tail. Between the wings, the tail and the nape there is looped decoration with two perforations. The space between the legs of the bird forms a loop. The claws are strong, and the hindermost of these stretches quite a long 


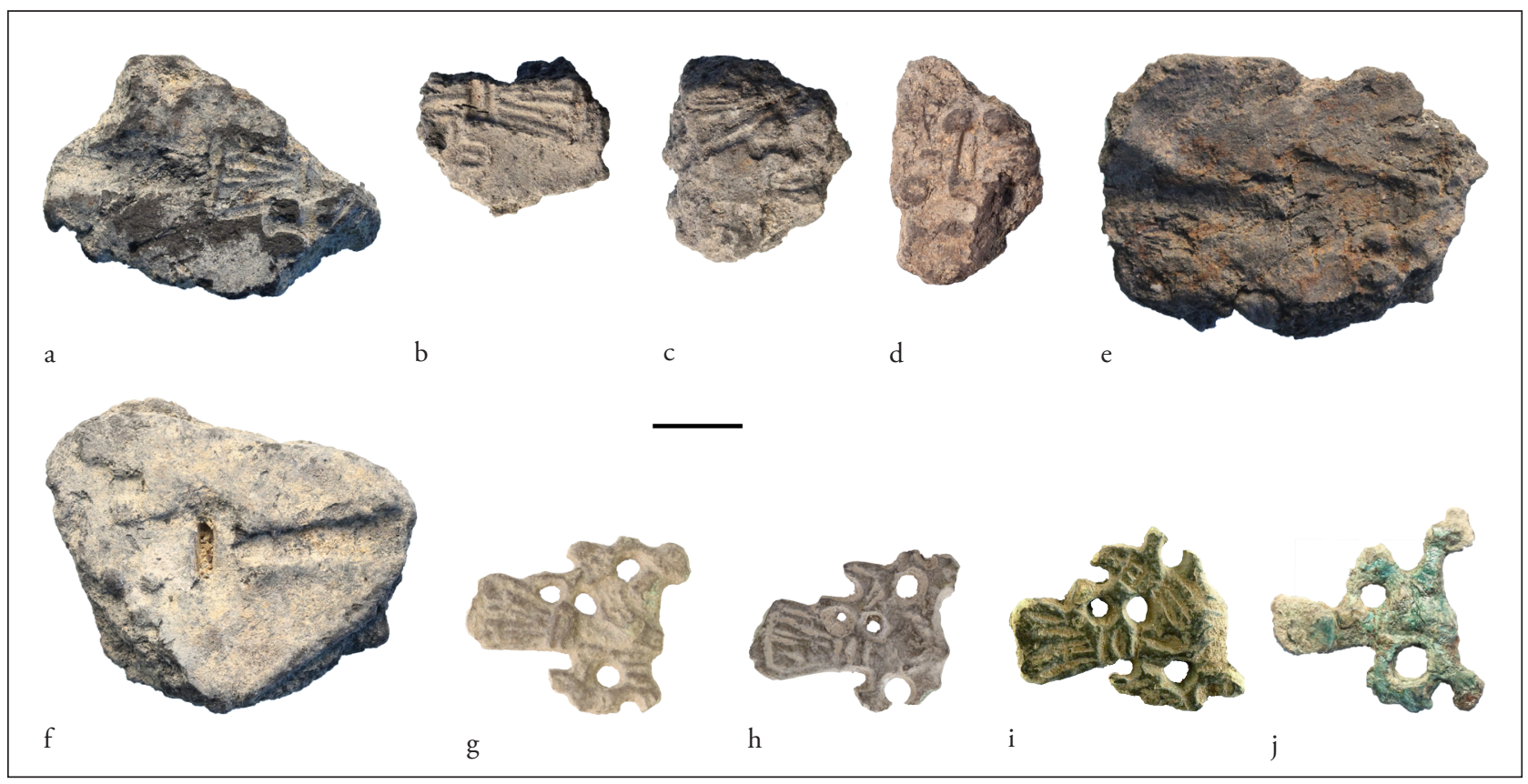

Figure 14. Bird-shaped brooches, Type 2. (a) ASR 13x3129. (b) x3492. (c) x3534. (d) x3474. (e) x3534. (f) x3129. (g) ASR 1375x130. (h) ASR 1689x281. (i) SJM 154x6. (j) ASR 11x4711. 1:1. Photo: SJM/HBC.

way back beneath the tail. On well-preserved specimens, vertical parallel lines mark the transition between the body and the tail. There is a total of 16 mould-impressions which can be assigned to this type in the workshop find (Figure 14a-f) while a number of counterparts have correspondingly been found locally on metal-rich sites (Figure 14gi), and one example is an archaeological find from Ribe (Figure 14j).

\section{Type 3}

This type depicts a bird whose wings are resting upon the fan-shaped tail and the beak is slightly hooked. On one well-preserved double mould an impression can be seen along with that of a circular brooch (Figure 15a). The impression is flat, with demarcation of the wing against the body as its only detail. The head is small in proportion to the body. ${ }^{11} \mathrm{~A}$ brooch of this type found by metal-detecting has a number of blisters on the body and may be a miscast (Figure 15b). Despite its irregular surface the pin-fittings were completed and the brooch will therefore have been used.

\section{Circular animal brooches}

The workshop assemblage from Ribe included at least 56 mould-fragments for the casting of openwork circular brooches (Table 2). Most of these had an outer diameter of around $2 \mathrm{~cm}$ but there are also circular frames down to only $1.5 \mathrm{~cm}$ diameter (Figure 15a). On many of the fragments it

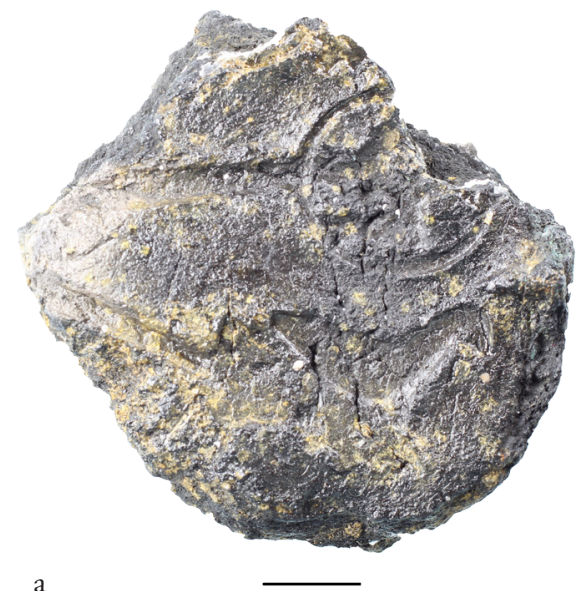

a

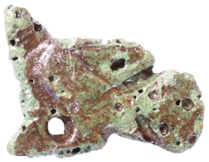

b
Figure 15. Bird-shaped brooches, Type 3. (a) ASR 13×3564. (b) ASR 1689x60. 1:1. Photo: SJM/HBC. 


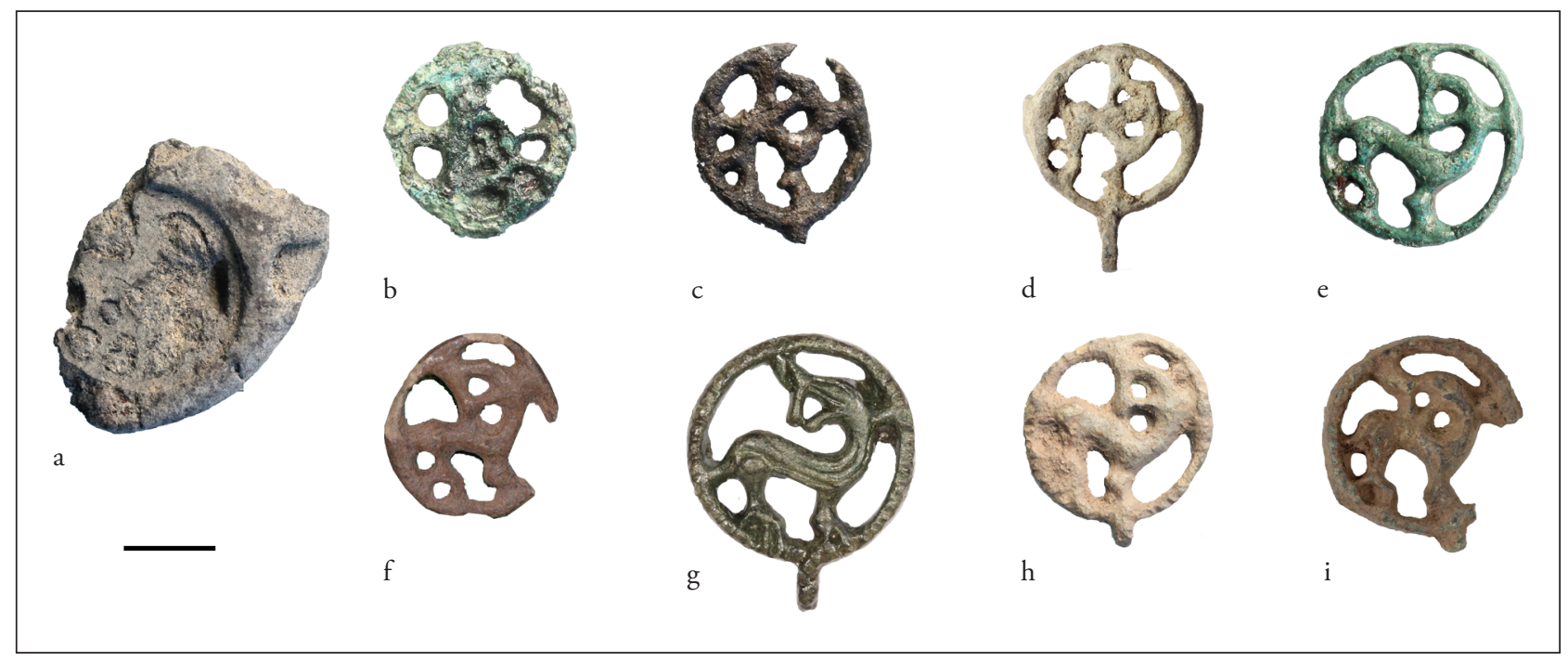

Figure 16. Circular animal brooches, Type 1. (a) ASR 13x3129. (b) ASR 13x3090. (c) x1093. (d) ASR 13x4255. (e) ASR 11x3260. (f) ASR 1995x1. (g) ASR 1021x2 (h) ASR 2344x268. (i) SJM 679x8. 1:1. Photo: SJM/HBC.

is not possible to identify the central design. The frame itself may be relatively broad and flat; in two ridges or decorated with a beaded rim.

\section{Type 1}

Circular animal brooches of the type that is also known as the Aalborg Group (Bertelsen 1992; 1993). The design is a backward-facing animal with an open mouth and a stylized pointed snout. The animal is set slightly turned within the frame and is often provided with a loop at the bottom of the frame (Bertelsen 1992). In the workshop assemblage from Ribe the type is represented by a lead model (Figure 7, 16d) and a mould-impression from the manufacture of this type. The fragment is rather battered, and some of the impression of the forepart and neck of the beast has been knocked off (Figure 16a). In addition to this piece two discarded brooches were found in the excavation, one of them clearly miscast (Fig. 16b) and the other lacking the final finishing work in the form of perforations for the pin-catch and pin-anchor. On the latter it would appear that the attempt to cast something to form a loop failed (Figure 16c) but the filing out of holes for the pin-fittings had started all the same. As a rule, brooches of this type would have had a cast-on loop but there are also examples without that (Figure 16e, f). It is possible that the openwork in the design could be used to fasten appendages, as in the case of the bird-shaped and Urnes brooches. This type is highly uniform in appearance, with differences residing in where details of the design have been put, or whether the frame is decorated. In the latter respect there are some very simple examples (Figure 16f) while others have a frame with a beaded rim (Figure 16g-h); one has a well demarcated face and a curl on the snout (Figure 16g) (Bertelsen 1993).

\section{Type 2}

This type depicts circular animal brooches with the Agnus Dei motive. Inside the frame there is a stylized beast whose back forms a horizontal, undulating line just above the centre of the frame. Fore- and hindlimbs are joined to this. Above the back of the beast is a conspicuous cross. On examples that have been produced in a more detailed style an eye, tail and a spiral-demarcated shoulder are visible (Figure 28a). The outer diameter is around $2 \mathrm{~cm}$. Nine mould-fragments from the Ribe workshop can be matched to this design (Figure 17a-f). These include three double moulds in which the circular brooch was cast along with an Urnes brooch (Figure 17e-f). There is also a highly abraded specimen with a pin soldered on to the reverse in the workshop assemblage (Figure 17g) and a detector-found specimen from the hinterland of Ribe (Figure 17h). This type has no soldered-on loop, but once again the holes between the legs of the animal could have served as loop holes for suspension. 


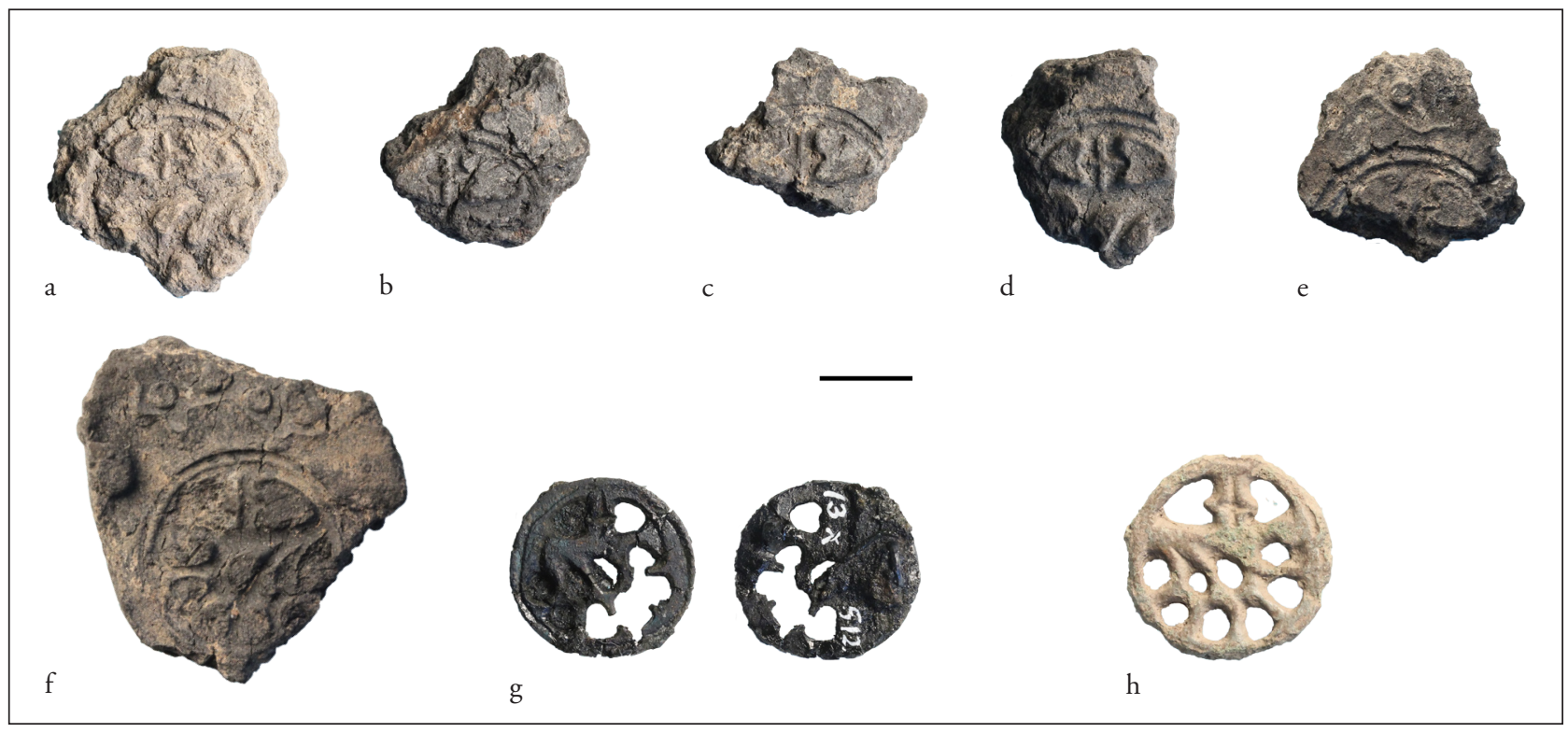

Figure 17. Circular animal brooches, Type 2. (a-c) ASR 13x3492. (d) x3520. (e) x3492. (f) x3522. (g). ASR $13 \times 512$ (front and back). (h) SJM 154x176. 1:1. Photo: SJM/HBC.

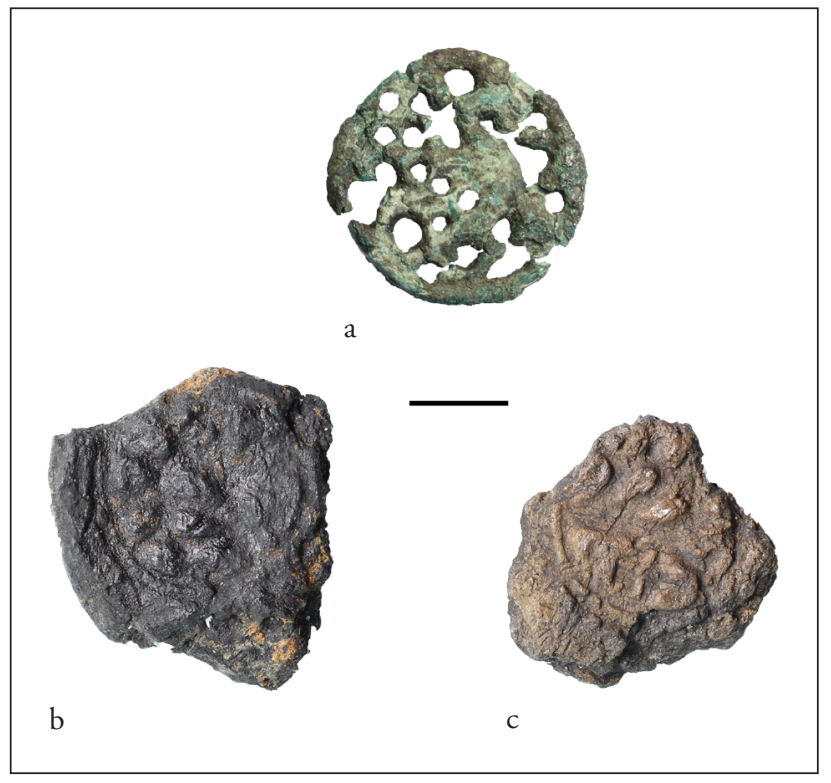

Figure 18. Circular brooch with animal design, Type 3. (a) ASR 13x3121. (b) x3492. 1:1. Photo: SJM/HBC.

\section{Type 3}

This brooch type has a circular frame which is a little larger than with Types 1 and 2. Inside the frame can be seen the body of an S-shaped animal or bird with a neck and bent head surrounded by Urnes-style looped decoration. The brooch looks like a hybrid of the Urnes-brooch and circular animal-brooch forms. There are two mould-impressions for such brooches, with profiled circular frames filled with Urnes-style decoration (Figure 18b) and one discarded or miscast brooch from the workshop layers (Figure 18a)

\section{The palmette brooch}

The products of the workshop included a type of brooch which up until a few years ago was a rarity in Denmark (Henriksen 2017, 26) (Figure 19). In this paper it is referred to as the palmette brooch, a name which refers to a core component of the design and its symbolism.

The palmette brooch is similar in size and construction to the other brooch-types presented above. A typical width is around $2,5 \mathrm{~cm}$, and in addition to a pin-catch and pin-anchor there is sometimes evidence of a loop. On one specimen from Ladby on Fyn the loop ring is preserved (Figure 20a). Although already one can see a range of varieties and stylistic variance amongst the examples found by metal-detecting, it is pretty much the same features which recur in the symmetrical design. At the bottom there is often an oval raised area which is occasionally modelled as a bearded human face (Figure 20a-b, f); in other cases as a ribbon-bow or palmette (Figure 20c-d, g-i). Vertically above this a more or less stylized palmette or ribbon-bow spreads out, and at either side two curving animal necks with heads project which meet above the palmette and enclose the central motifs in a heart-shaped frame. In Christian iconography the palmette is synonymous with the Tree of Life and the Cross (Karlsson 1981, 117). It occurs in Mammen, Ringerike, Urnes and Romanesque art on runestones, in ecclesiastical art, 


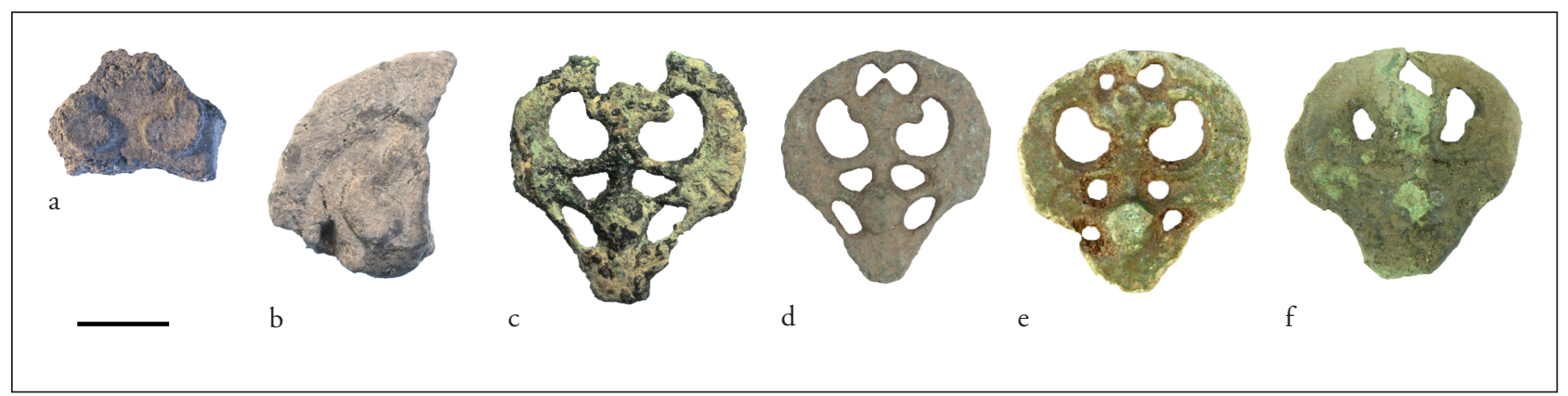

Figure 19. Palmette brooches. (a) ASR 13x3126. (b) x3474. (c) ASR 13x1139. (d) ASR 1689x256. (e) SJM 154x1. (f) SJM 679x5. 1:1. Photo: SJM/HBC.

and on minor objects including coins and items of jewellery (Jensen 1995, 54; Karlsson 1981; Vellev 1981, 59f). Trefoil palmettes appear on cruciform pendants of the $11^{\text {th }}$ century (Vellev 1981; Jensen et al. 1992, Cat. No. 19; Staecker 1999, e.g. Cat. Nos. 22, 23, 25, 39). On a circular animal brooch four symmetrically arranged palmettes mark the terminals of the arms of the cross in the composition's modified cross shape (Bertelsen 1992, 245, 2002a, 30, Pedersen 2014, 210).

The palmette design often appears in connection with or in between snake-like beasts, on occasion as a linking component (Karlsson 1981, figure 1-2). The linkage can be seen as expressing a connectedness and association rather than the pacification of some negative force (Karlsson 1981, 117; cf. Wood 2014).
The design, in which the palmette almost invariably constitutes the central component, is probably just such a Tree of Life surrounded by snake-like beasts or with the latter growing from it - possibly godly rather than diabolic symbols. In several cases a human mask, sometimes bearded, terminates the frame of the brooch at the bottom. Human figures or masks, palmette motifs, the Tree of Life, Cross and beasts are compositional elements often seen together in Late Viking-period or Romanesque art (Pedersen 1981, e.g. 69, 87). In some cases the human replaces the bow/palmette which connects the animal heads (Pedersen 1981, 70, figure 3), while the palmette is contrastingly placed where the mask occurs on some of the brooches. Several of the elements appear, therefore, to be synonomous, which is, as it were, the palmette or the Cross.

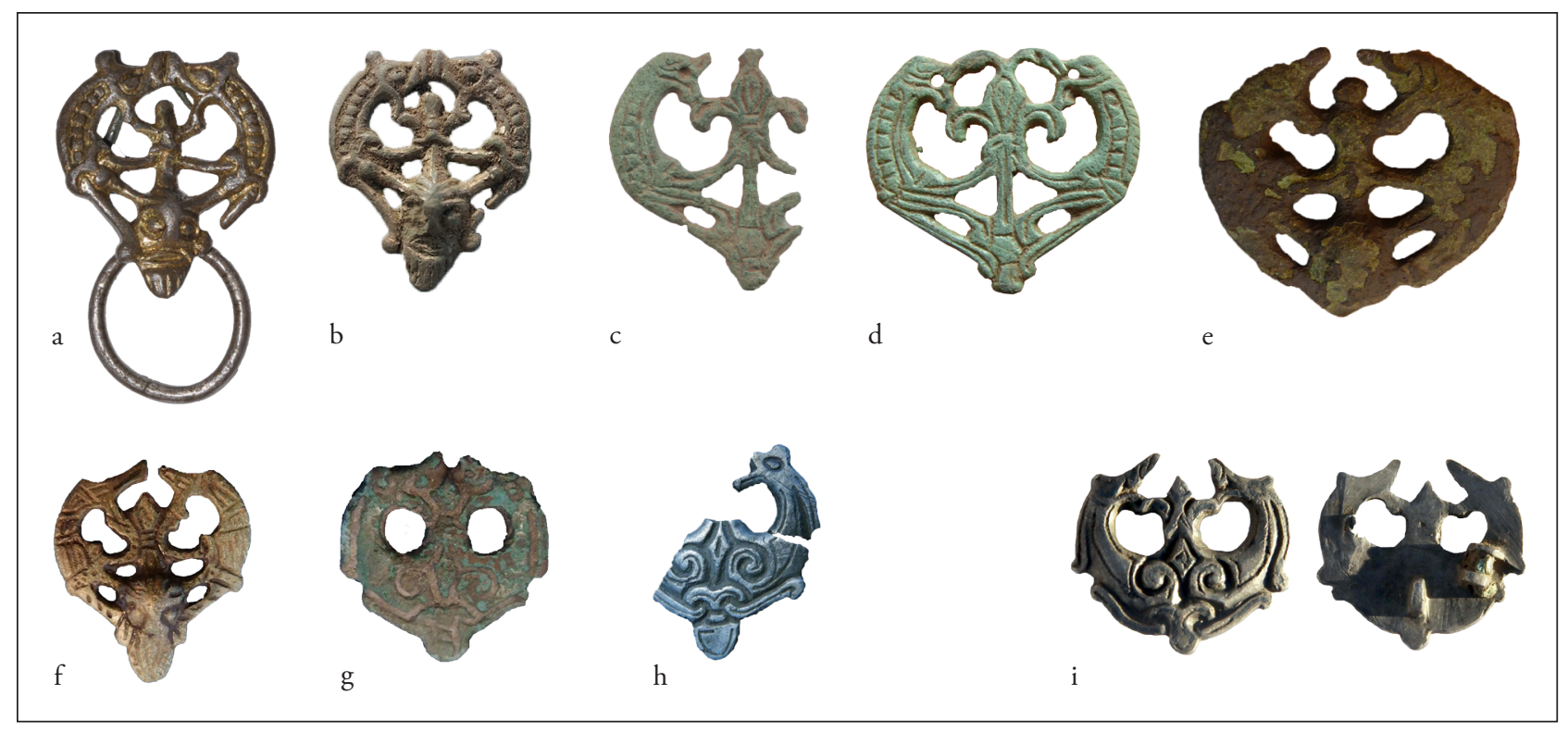

Figure 20. Examples of palmette brooches from elsewhere in Denmark. Without scale. (a) ØFM 445x1. Photo: Claus Feveile. (b) VHM 100x3061. Photo: Louise Stalschmidt. (c) OBM 9867x341. Photo: OBM. (d) ØFM 620x74. Photo: Claus Feveile. (e) HAM 4971x12. Photo Anders Hartvig. (f) MLF1905x54, copper-alloy. (g-h) MLF1930x?, x5, copper-alloy/ silver. Photo: Torben Christjansen. (i) ØFM 620x670, silver. Photo: ØFM. 
Since the other components have counterparts in Christian symbolism, could the mask perhaps portray Christ?

\section{Cross-shaped objects and buckles}

Another product was the small double cross with no sign of any loop, holes or anything else which could show how it was used (Figure 8, 21a-b). The double cross, known as the crux gemina or patriarchal cross, is a rare occurrence amongst the assemblage of detector finds or in archaeological contexts (Staecker 1999, 153-4). On the other hand a number of fine pendant crosses shaped as Greek or Latin crosses do appear amongst the detector finds of this period, both in de luxe editions of precious metal and cast in lead or bronze (Bertelsen 1993, 4; Jensen et al. 1992; Staecker 1999; Søvsø and Knudsen 2019, 134-6). One possibility is that the double crosses were intended to be used as pendants with a drilled hole for suspension or a loop soldered on. Alternatively they could have served as ornaments attached to other types of object. In addition, one example of three connected buckles shows that the output of the workshop also included other types of dress-accessory (Figure 21c) (Bergmann and Billberg 1976, 206).

\section{Some observations regarding the workshop repertoire} Taking into account the many fragments with unidentifiable imprints, it seems likely that additional types might have been produced in the workshop. The finds from metal-rich sites in the hinterland of Ribe might give an impression of some of these workshop products. They cannot be associated with the workshop with any certainly but can be noted as possible suggestions as to what the repertoire also may have included (Figure 22). A few types of bird-shaped brooches stand out in particular (Figure 22a-e, f-g, h-i).

The comprehensive find material from the Ribe workshop gives new insights when it comes to several aspects. It stresses the connection, contextually and symbolic, between the brooch types represented in the material. It has earlier been cautiously suggested that the animal on the Aal-

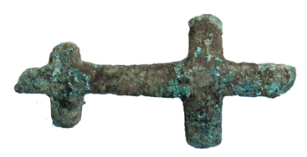

a

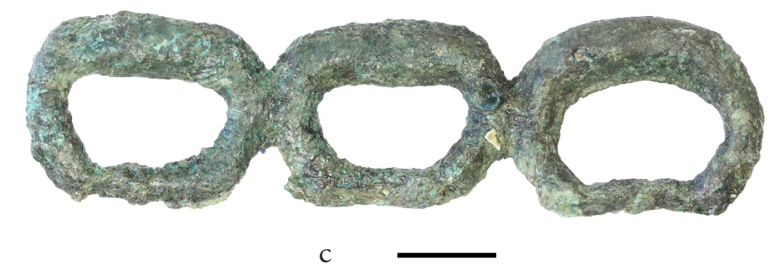

Figure 21. Double crosses. (a) ASR 13×3129. (b) x3535. (c) Three buckle loops still connected as cast ASR 13×3152. 1:1. Photo: SJM/HBC.

borg group type are perhaps another, possibly a bit earlier, version of the Agnus dei motive (Bertelsen 1992, 245, 2002a, 30, Pedersen 2014, 210). The workshop production of both types, stresses the close relationship between these two motive variants. The decorative elements used on the brooches all seem to be based in Christian symbolism but expressed through Scandinavian stylistic tradition (Bertelsen 2002a, 28-29; Gotfredsen 2002, 42). In other words, the workshop repertoire seem to be saturated with Christian symbolism.

Another important observation is the range of quality of different brooch types among the Ribe workshop products. There is a large difference in artistic quality between for instance the Urnes brooch type 1 and type 2-3. Slightly miscast products were finished, sold and used, probably at a lower price. Altogether this reflects a production targeting a broad customer base rather than the works of a number of different craftsmen, some more professional or talented than others. This evidence is a breakthrough in order to understand the background for the range of quality seen among the detector finds of these brooches all over Denmark. 


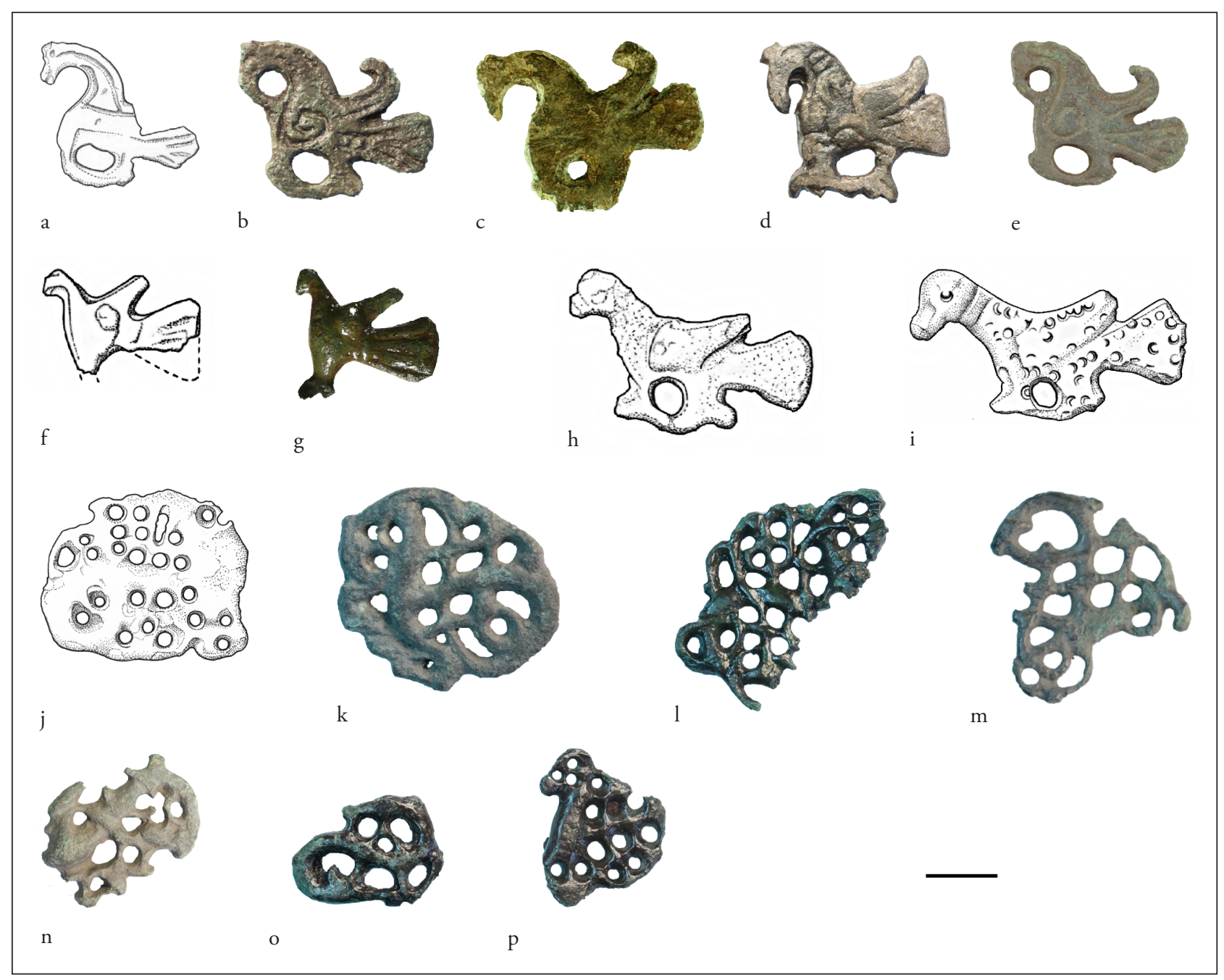

Figure 22. Other brooch finds from the hinterland of Ribe. (a) ASR 491x150. (b) ASR 872x140. (c) ASR 1425x63. (d) ASR 1990x1. (e) SJM 154x144. (f) ASR 440x801. (g) ASR 1689x135. (h) ASR 440x603. (i) ASR 440x789. (j) ASR 491x148. (k) ASR 2321x1. (I) ASR 1990x2. (m) ASR 2344x57. (n) SJM 748x1. (o) ASR 872x69. (p) ASR 872x76. 1:1. Photo/drawings: SJM/HBC.

\section{The workshop in Aalborg}

In the course of excavations in the area around Budolfi Church in Aalborg, in 1981, 2015 and again in 2017, remains of one or more bronzecasting workshops which used the same techniques and had a repertoire of production that was similar to that at Ribe was found (Figure 2327) (Jensen 2018). Crucibles were found as early as 1981, while an excavation of 2015 produced fragments of a couple of lead models, one of them (Figure 24b) possibly the lower part of a model for a variant of Urnes brooch which is known, inter alia, from Nørholm west of Aalborg, from Als in Himmerland (Figure 24c), and from Mollerup between Randers and Viborg (Pedersen 2010, 209).
In 2017, in connection with the construction of a sewer trench in Algade immediately south-east of Budolfi Church, further traces of workshop activities were found: this time in the form of several well-preserved waste products from bronzecasting in the layers affected. The trench lay not only within the actual medieval street itself but also cuts partly into the medieval plots that lined the street. Excavated there were, amongst other things, floor layers and a furnace pit which may be from a workshop itself. It is quite conceivable that outside of the line of the trench there are still intact and well-preserved remains of the workshop. Amongst the finds there are 60 crucible-fragments or complete crucibles, ingots, melting waste, 15 clay moulds, and both finished and miscast pieces of jewellery (Figure 25-26). The casting waste, ingots 


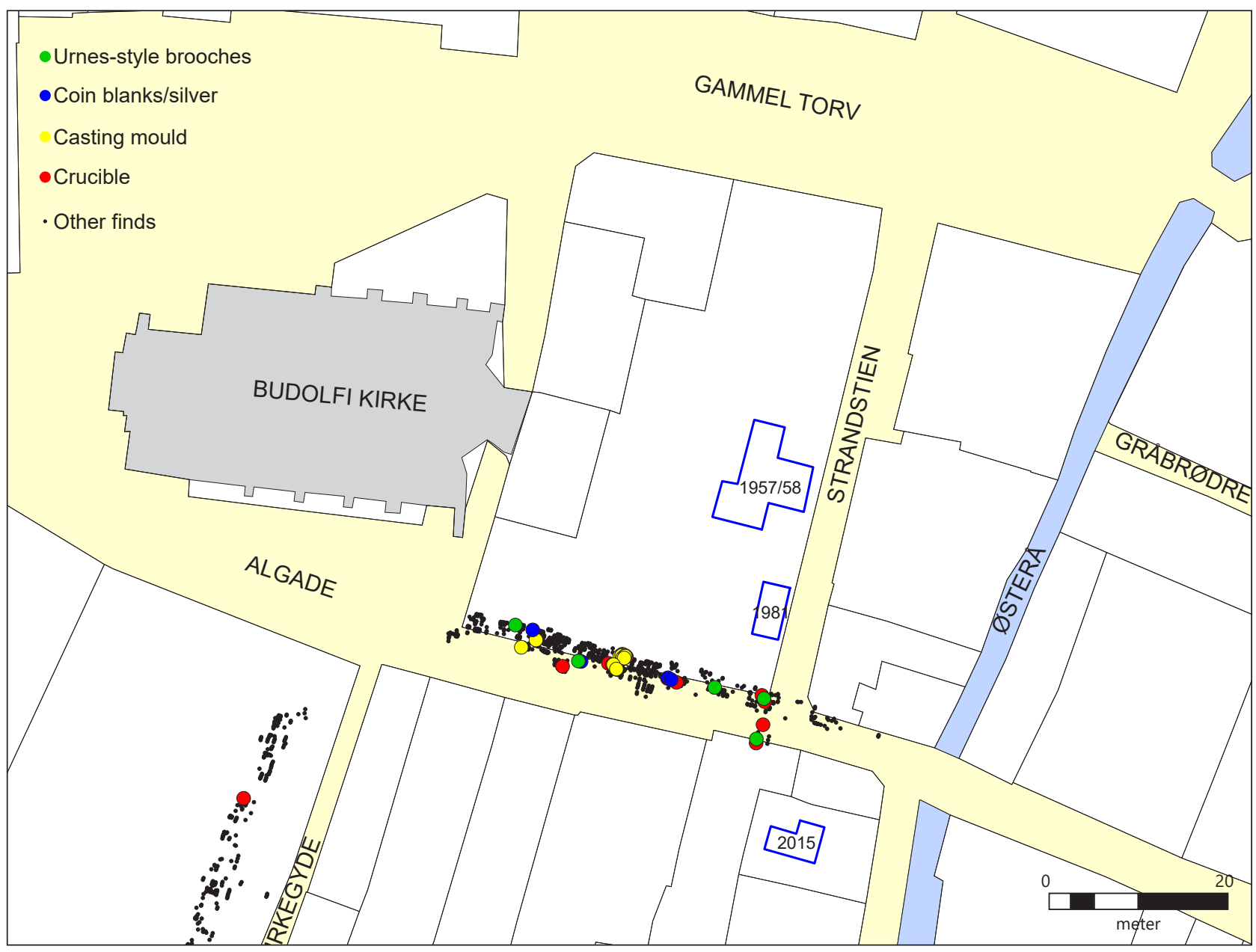

Figure 23. Plan showing the excavations referred to and the 2017 finds around Budolfi Church/Algade in Aalborg. Illustration: Christian Vrængmose Jensen.

and items of jewellery are of a brass-like copper alloy. The finds include both moulds for and readycast Urnes brooches. Two brooches were discarded or lost before they had a pin attached (Figure 26c-d) while a third has both its pin-catch and an attached loop (Figure 26e).

The metal finds also include two miscast circular animal brooches (Figure 26f-g). There is additionally a mould for a small pendant cruci- fix (Figure 26h) and a nearly matching complete pendant of a lead-tin alloy (Figure 27a). This type of crucifix is dated from comparable finds to the $11^{\text {th }}$ century (Jensen et al. 1992, Cat. No. 15; Staecker 1999, 473-4, 483). A small, bright brassy bird-shaped brooch that was also found in the area could be suggested to be another workshop product (Figure $27 \mathrm{~b}$ ). The finds assemblage from the sieved strata also shows that objects of

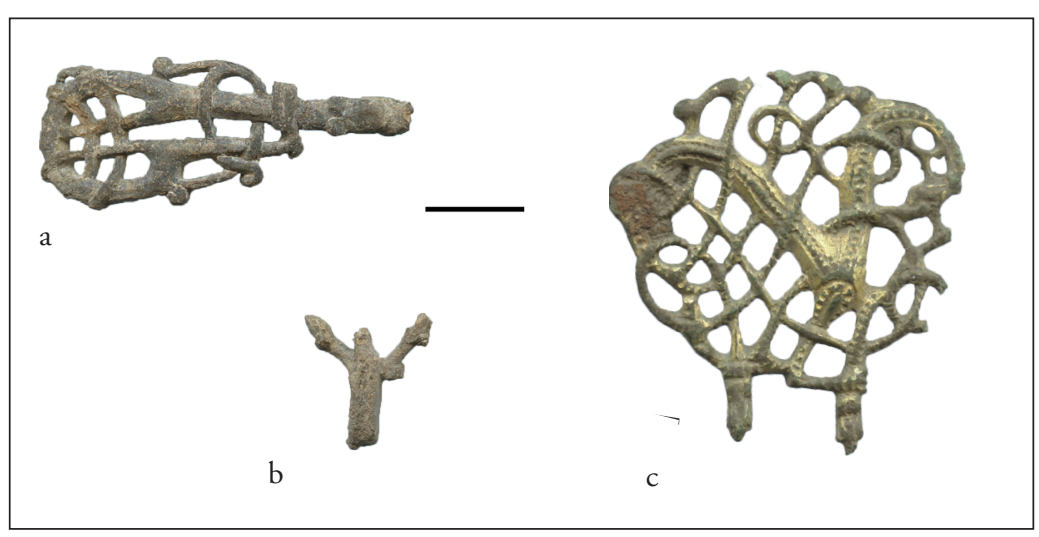

Figure 24. (a-b) Finds of lead models from Algade, Aalborg ÅHM $6488 \times 42, x 41$. (c) Urnes brooch from Als, Himmerland. 1:1. Photo: ÅHM. 

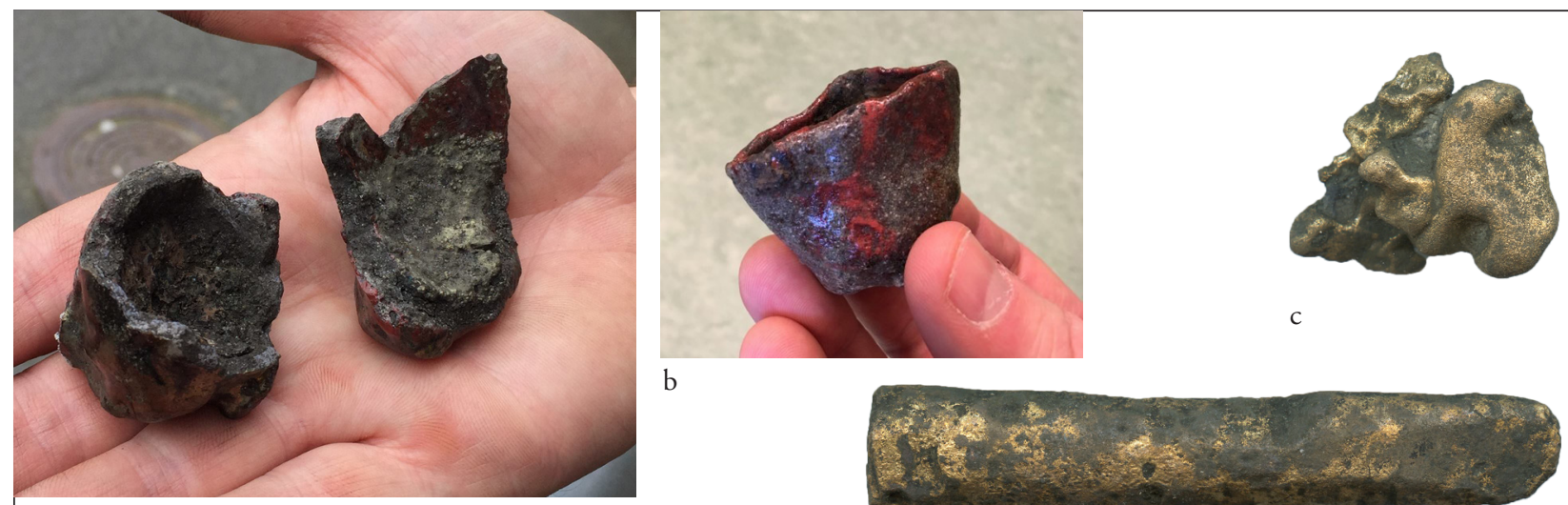

$\mathrm{b}$

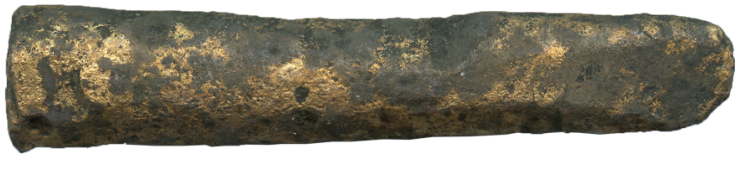

d
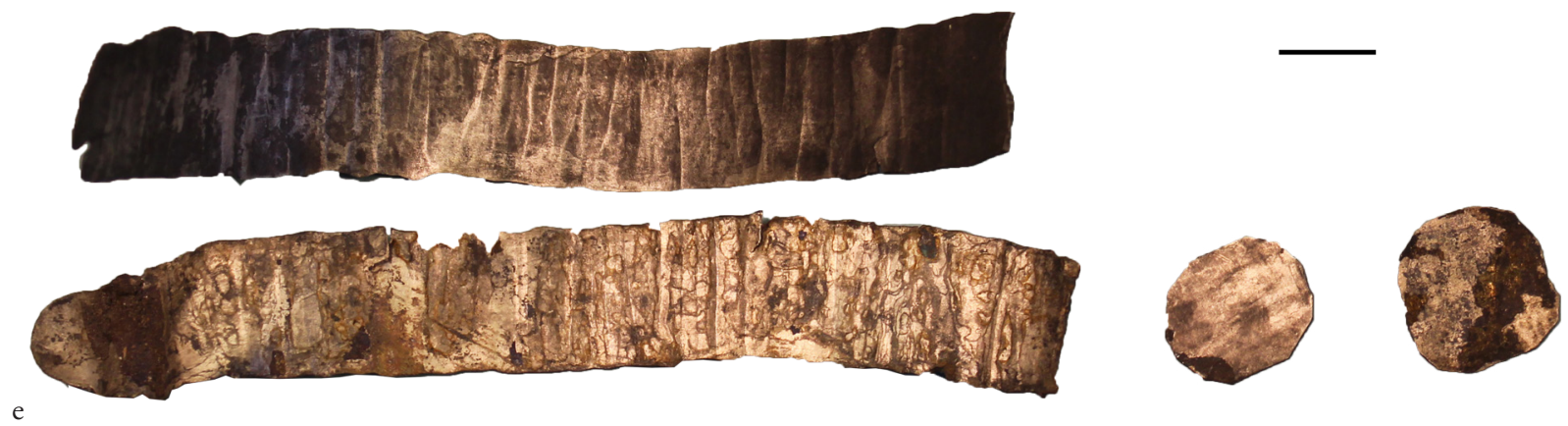

Figure 25. Production waste from Algade and Strandstien. Crucibles: (a) ÅHM 6713x1682, x1840. (b) ÅHM 1239x9. Melting waste: (c) ÅHM 6713x2139. Ingot: (d) ÅHM 6713x1847. Metal strips and cuts: (e) ÅHM 6713x1681, x1739, x1696, x1003. 1:1. Photo: ÅHM.

sheet metal were manufactured here, including tweezers and sheath mounts, probably produced in the same period as that in which the brooch workshop was operative (Bergmann and Billberg 1976, figure 149; Feveile 2017, 78).

Moreover, in the layers of the brooch workshop silver strips and cut blanks were found which probably derive from the minting of coins that is known to have taken place in Aalborg in the last quarter of the $11^{\text {th }}$ century (Figure 25e). Most important in dating terms is a coin of The Holy King Canute which was indeed struck in Aalborg's own mint. A dendrochronological dating to AD 1082 from the excavation of 1981 should also be highlighted. It has to be considered probable that some of the archaeologically identified bronzecasting activity also dates back to the late $11^{\text {th }}$ century. The finds from the pipe-trench excavation of 2017 show, furthermore, that the metalworking activities carried on into the $13^{\text {th }}-14^{\text {th }}$ centuries. Amongst other things belt buckles and ring brooches were manufactured in this period. In Strandstien immediately east of Budolfi Church what is known as the 'pinmaker's workshop' of the second half of the $13^{\text {th }}$ century was excavated as long ago as 1957 . Inter alia, the activities here included the production of artefacts of sheet metal and the casting of objects in stone moulds (Kock 1992, 340-2; Riismøller 1960). This area was, in other words, intimately associated with the practice of metalworking and the production of small artefacts of copper alloy and lead-tin over several centuries.

\section{The range of wares of the workshops and their customer base}

The workshop finds in Ribe and Aalborg have a number of common features. Not just in respect of the technology and the repertoire of products. In Ribe, the comprehensive finds evidence allows for a more detailed insight into the range of the product repertoire and the extent of the production of the 


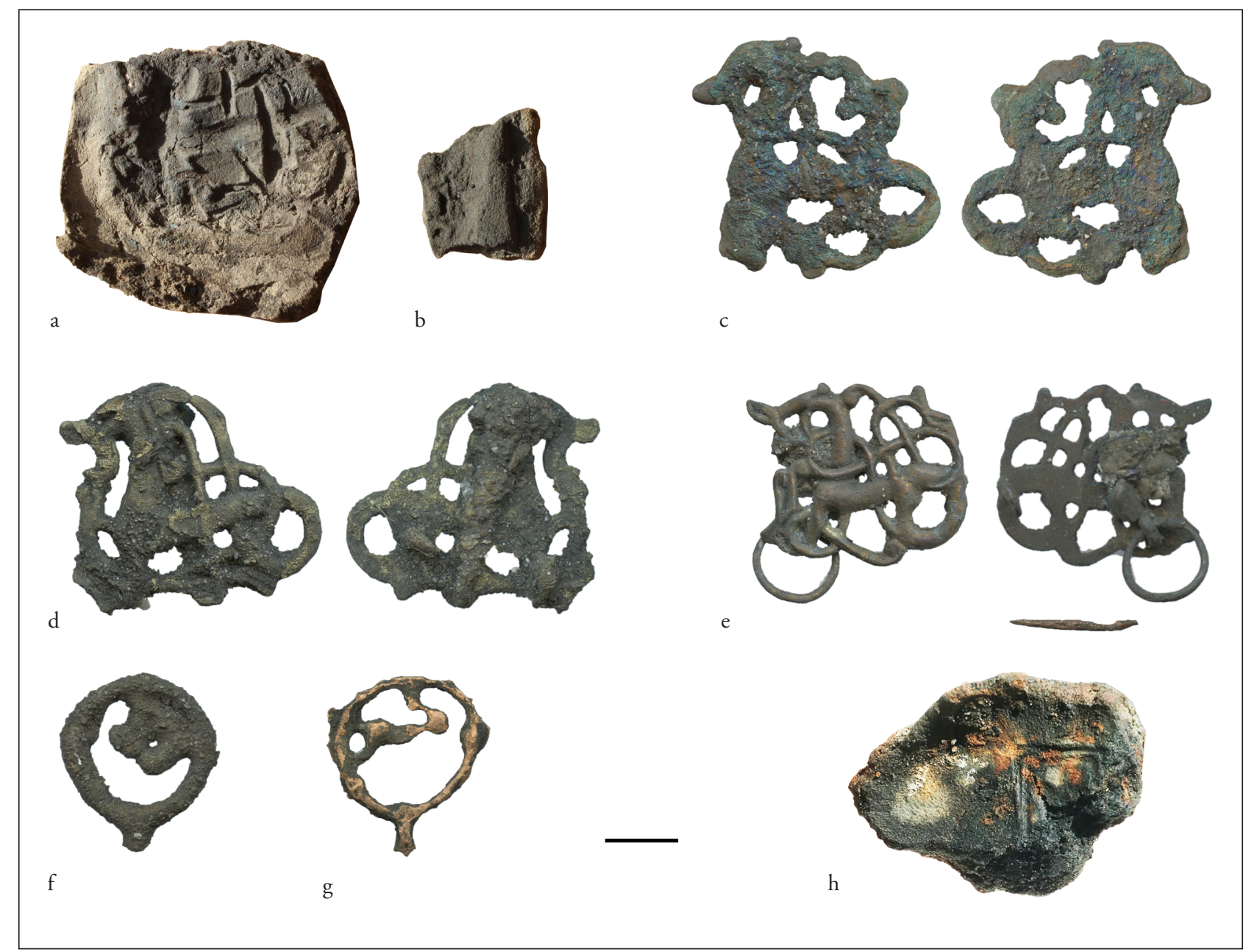

Figure 26. Moulds and brooches from the excavation in Algade, Aalborg. (a-b) ÅHM 6713x2082, x2083. (c-d) (fronts and backs), ÅHM 6713x1738, x1649. (e) 6713x1645 (front and back). (f-g) ÅHM 6713x1935, x2089. (h) ÅHM6713x2550. 1:1. Photo: ÅHM.

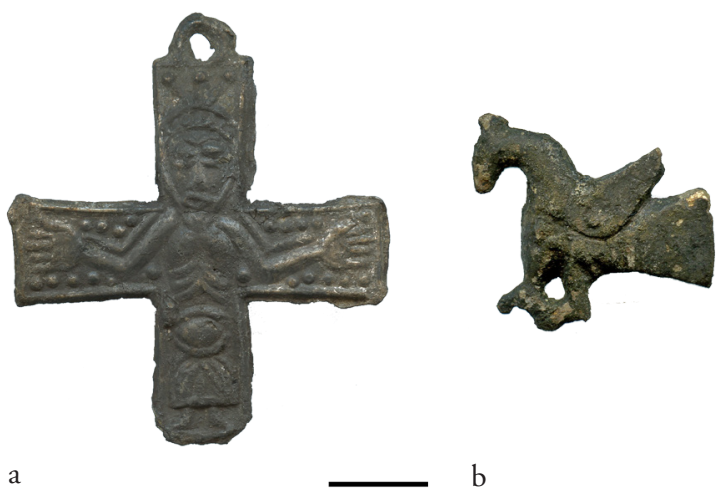

Figure 27. Other finds of jewellery of the $11^{\text {th }}$ and $12^{\text {th }}$ centuries, Algade, Aalborg. (a) ÅHM 6713x1669. (b) ÅHM 6488x14. 1:1. Photo: ÅHM.

different brooch types (Tab. 2). Most mould-impressions are from Urnes brooches, followed by impressions from bird-shaped brooches and circular animal brooches of Type 2 . The numerical preponderance of Urnes brooches in relation to the other types is corroborated by the analysis of detector finds (Christiansen 2017, tab. 4.4; Gilså in press) and by counts from a number of local museums. ${ }^{12}$ Circular animal brooches of Type 1, small crosses and palmette brooches appear from the number of surviving mould-impressions from the Ribe workshop to have been manufactured in lesser volume here. The composition of the repertoire underlines the religious symbolism and the inter-association of the various brooch-types which otherwise are known only as stray finds in Denmark.

One important observation is the fact that brooches of varying artistic quality came from the workshop in Ribe. A similar range of quality, in terms both of the materials selected and execution, is well known from many metal-rich sites (e.g. Andersen 2015, 55). The range of variation is also convincingly reflected in the finds assemblages from the same sites (e.g. Figure 10b, 11a). This has readily been interpreted as reflecting the abilities 
of more or less professional artisans, or degeneration over time (Christiansen 2017, 93; Lønborg 1994, 371; Pedersen 2010; Ramskou 1957, 199200; Westergren 1986). The workshop find from Ribe, however, reveals that the differences in quality here reflect the range of goods offered from a single operative workshop, which must have been targeted at a group of customers of varying economic means. The brass-like alloy that was used both in Aalborg and in Ribe was probably intended to make the brooches look like precious metal and thus more valuable than they really were.

\section{Local production and regional types?}

There is generally a lack of recent analyses of detector-found brooches on a national scale; but recently a study of the Danish finds of Urnes brooches, their typology and distribution, has been made (Gilså in press). Regional studies of objects found by metal-detecting in the Limford area and north-eastern Fyn show the potential for mapping the overall tendencies represented by large numbers of finds in an area (Back, Christiansen and Henriksen 2019; Christiansen 2017; Henriksen 2017). In the case of the Urnes, bird-shaped and circular animal brooches in northern Jutland it could be concluded that there was more copious production compared with brooches of the preceding period, and a greater degree of standardization (Christiansen 2017, 84, tab. 4.3). It has been proposed that the most finely finished brooches could be from urban workshops and may have been the models for local copies of brooches, with similar designs but of lesser artistic quality. It has been suggested by Torben Trier Christiansen that the trend-setting urban workshops of the region are to be sought in Viborg and Aalborg (Christiansen 2017, 93). The workshop find in Aalborg came to light shortly after the publication of Christiansens study, and has confirmed that aspect of the theory concerned with urban production. The volume of finds from Aalborg does not allow for any greater insight into the repertoire of the workshop, but based on the considerable variation attested in Ribe it is reasonable to suppose that the range of quality at the metal-rich sites in the hinterland of the town may indicate its repertoire.
On the basis of Christiansen's study (Christiansen 2017, 84-104), and from the trends of the detector evidence more generally, the image appears to be characterized by parallels that appear over large areas and by standardized types rather than local or regional varieties. Starting from the workshop finds, the small bird-shaped brooches of Type 1 from the Ribe workshop (Figure 13) and the Urnes brooches from the Aalborg workshop (Figure 26ce) can be suggested as 'local workshop designs' which achieved a degree of regional distribution. This, however, is a view that could change very rapidly with new finds. Most of the other products from the Ribe workshop and detector-found brooches from the hinterland of the town thus have counterparts in other parts of Denmark, e.g. Figure $11,{ }^{13} 12,{ }^{14}, 14,{ }^{15}$ (Pedersen 2001, 28-9), $22 \mathrm{~g},{ }^{16} 22 \mathrm{o},{ }^{17}$ (see e.g. Andersen 2015, 54), and $22 \mathrm{p}^{18}$ (Ramskou 1957, 199-200). The circular animal brooches, which were manufactured both in Aalborg and in Ribe (Type 1) (Figure 16, 26f-g), are common finds in the Limfjord area - hence the term Aalborg Group (Christiansen 2017, 87) - but are found in exactly the same form at many other Danish sites (e.g. Andersen 2015, 55). ${ }^{19}$ The circular animal brooch with a cross over the back, Ribe workshop Type 2, similarly occurs at many sites (Pedersen 2004, 71) (Figure 28). ${ }^{20}$ In summary, a great deal of caution is required, and only with care should certain varieties be regarded as regional.

Lead models and miscast brooches are often automatically understood to be markers of local manufacture but the evidence is often less certain or based upon misunderstandings. The patrix die from Sebbersund, for instance, is not specifically for the production of circular animal brooches of the Aalborg-group type and does therefore not count as a proof of production of this specific brooch
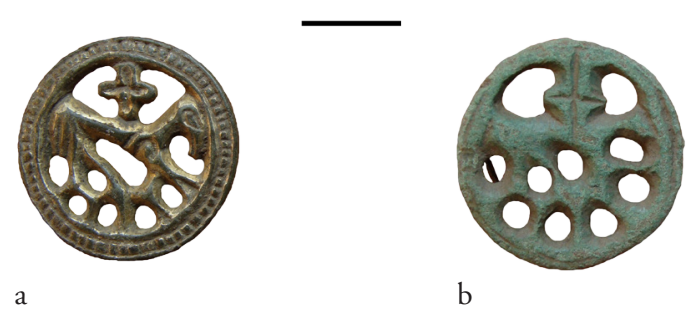

b

Figure 28. Examples of circular animal brooches from north-eastern Fyn. (a) ØFM 425x150. (b) ØFM 564x40. Photo: Claus Feveile. 
type (e.g. Bertelsen 1992, 251). The presumed remains of a clay mould stuck together with a miscast brooch seem instead to be the rusty remains of an iron pin stuck on a finished brooch (Christiansen $2017,91-2) .{ }^{21}$ Furthermore, many miscast or worn out brooches were nonetheless used as items of jewellery (Figure 10c, 15b). If they lacked pins, they could be sewn on to the costume instead (Bertelsen 1994, 348-9, 358). ${ }^{22}$ Consequently, a miscast brooch would not necessarily have been discarded at the production site but could have had a longer functioning life. In a similar way, it is uncertain when an object was definitely used as a model where it was found and when it has ended up in some different context (e.g. Bertelsen 1994, 353). One could question whether models were perhaps sometimes secondarily used as jewellery or amulets. And were the models inevitably of lead, or could copper-alloy models, or indeed finished items, be used (Figure 29)?

The brooch finds from the hinterland of Ribe have been inferred probably to be products of the workshop in the town above (Figure 9). This is not a blanket rejection of the possibility that local production may have taken place. But with the Ribe area as a case study, the most convincing interpretation is that it was the workshop in the town which provided the hinterland with brooches of various qualities rather than that copying or alternative brooch-production took place locally, or in the hands of itinerant craftsmen. Such production in the immediate area could hardly have competed with the mass-produced and varied range that was manufactured in the town. In other parts of Denmark, distant from the towns that were in existence at that time, the situation may have been different. Before the workshop site was excavated in Ribe, it was first and foremost finds from metal-detecting in the hinterland of Ribe which provided evidence of the distribution and use of Urnes, bird-shaped and circular animal brooches in the area. Only a handful of brooches had been found in excavations in the stratigraphy of the town before 2011-12, when the workshop south of the Cathedral was discovered. There was thus nothing to indicate that it was in the town that production was located, and where there must also have been a considerable quantity of brooches in circulation. In addition to the fact that it is good fortune that the workshop

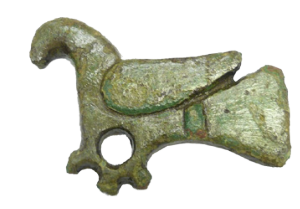

a
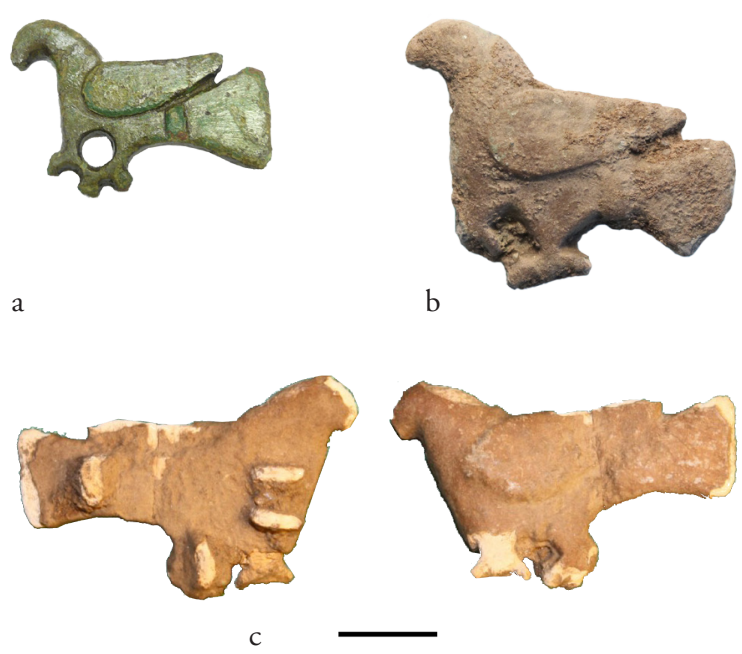

Figure 29. Possible models for bird-shaped brooches? (a-b) Copper-alloy birds with smooth reverse sides ASR $872 \times 65$, ASR $872 \times 200$. (c) Lead bird with remains of pinfittings and a loop ASR 872x150 (front and back). Photo: SJM/HBC.

was found and that, relatively, so much of it was preserved, it was crucially important in relation to the retrieval of a major collection of finds that the layers were systematically water-sieved.

With the regularly occurrence of several of the brooch-types at the same sites in mind (Beck, Christiansen and Henriksen 2019; Feveile 2017, 59) along with the inter-association demonstrated above between the types, one should presumably put the Urnes, bird-shaped and circular animal brooches together under the microscope and look at their composition and variance in order to try to define the operative area and output of a workshop. Other contemporary metal artefacts (Feveile 2017) which can indicate workshop milieux involving various forms of metalworking (cf. the workshop finds from Aalborg and Lund) could also profitably be brought into an analysis of that kind.

\section{Social and religious context}

Alongside the presence of the king and the Church, and together with minting, church-building and social organization, craft and trade were important factors in the development of urban communities in $11^{\text {th }}$ - and $12^{\text {th }}$-century Denmark. These evolved into centres of royal and ecclesiastical administration and of trade and specialized craftwork- 
ing. The Church's changed role, from that of an exclusive and elite-oriented missionary Church to a social power with great ideological, political and economic influence, came to the fore in the same period, amongst other ways through the formation of parishes and the construction of timber churches (Carelli 2001, 99 and 235-6; Kristensen and Poulsen 2016, 91-2; Roesdahl 2004). The urban environments provided suitable locations for the permanent workshops and the serial production of brooches, and as shown above there clearly seem to be a link between the activities of the Church in this period and the large quantities of detector-found brooches with religious symbolism (Pedersen 2014, 223).

In Ribe, the workshop was located on the plot south of the Cathedral which was probably in the possession of the Church throughout the period. The change in use of the area after the middle of the $11^{\text {th }}$ century provided space and the opportunity for the founding of the workshop and the serial production of brooches of the following decades. Could this be a piece of evidence that the Church was the principal agent in the production and distribution of the brooches? The use of small tokens of baptism/amulets with Christian symbolism was no new phenomenon at that date, and it must have been a familiar tack of the Church to expand what it offered in this way, concurrently making a profit out of it.

From the 1070 s through to 1180 , one can see a close relationship between minting and other metalworking in Lund. Coins were struck in the same workshop context in which a bronzecaster was producing jewellery in the 1070s, and coin brooches were also manufactured here (Carelli 2012, 86; Cinthio 1999, 45; Kristensen and Poulsen 2016, 102). Several areas with workshop activity have been excavated, and as early as the mid-11th century a large number of churches had been raised. In the present context, particularly to be noted is the linkage between the so-called Urnes workshop and a workshop area with extended continuity both back and forwards in time, and its location immediately adjacent to a plot that was in the hands of the Church (Wahlöö 1976, 20).

Some of the same features can be seen in Aalborg, where the brooch workshop and the mint were located side-by-side and immediately along- side Budolfi Church, the timber predecessors of which can be dated to the $11^{\text {th }}$ century (Kristensen and Poulsen 2016, 85). The close physical connection of the brooch workshops with minting in both Lund and Aalborg also implies a connection between this production and the presence of the royal authority.

\section{Conclusion}

The three brooch-types that are discussed above were introduced within a relatively short period of time in large quantities compared with other medieval artefact-types. Two workshops found, in Ribe and Aalborg respectively, represent key breakthroughs in terms of allowing us to place the large number of detector finds in a wider context and to understand the background to their distribution. The common features observable in respect of the location of the workshops and their range of products together suggest that this manufacturing was organized and targeted rather than haphazard or scattered, and that it was based primarily in urban contexts. The detector finds reinforce the image of the artefact-types as homogeneous and standardized, and a more detailed study of the finds of all three broochtypes from Denmark would be able to paint an even clearer picture, possibly also defining areas with other operative workshops in the decades around the year 1100. A close association with minting in Lund and Aalborg indicates that the royal authority played a role in some cases, but in Ribe most of the evidence implies that the Church was the most important agent. When it comes to the theories about a specific connection between the Urnes brooches and the Danish kingdom and Danish identity, the find of the Urnes brooch mould from Sigtuna seem to disprove this.

The differences in quality in both workshop and detector finds, both in respect of artistic quality and the raw materials used, show that this production must at the point of origin have been aimed at a relatively broad market. This may be an aspect of a strategic initiative that, at the same date as the workshops in Lund, Ribe and Aalborg, was underway or imminent in several other towns. At present, a combination of town, church and mint in the period AD 1050-1150 together with the 
brooch finds from the hinterland can reasonably be used as indicators of where workshops were located. On the basis of workshop finds in the diocesan towns Ribe and Lund, Viborg, ${ }^{23}$ Aarhus, Schleswig, Odense, ${ }^{24}$ and Roskilde are obvious candidates. But as the workshop discovered in Aalborg shows, there are other towns which emerged in the middle of the $12^{\text {th }}$ century (cf. Kristensen and Poulsen 2016, 66) that may have had operative brooch workshops. ${ }^{25}$

These activities could have been one strand in the more demotic diffusion and adoption of Christianity. The brooches may have been baptismal tokens, like both locally produced and imported small brooches of the Viking Period, but in this case in the form of more organized and extensive, local manufacture. With a view to the later, dispersed production and trade in religious souvenirs associated with pilgrimage, it is also possible that the production of the brooches in the ecclesiastical centres which the towns also served as at this juncture was an additional element in their appeal, providing them with holy, inherent powers. The brooches could have had a symbolic significance but also an economic one for the Church. At the same time they were attributed with a protective value for the wearer, so that there were multiple beneficiaries.

\section{Acknowledgements}

The research project is supported by The Agency for Culture and Palaces, Denmark grant MFO20.2017-0012.

\section{Notes}

4. In the new detector-find recording platform DIME the terms animal loop brooch of the Aalborg type or animal loop brooch of Urnes and Agnus Dei type are employed.

5. https://www.metaldetektorfund.dk/. Search: Genstandstype: Guds lam fibel-Agnus Dei fibel.

6. Collection of data made by Mette Højmark Søvsø in 2019. Article in prep.

7. An example on a fragmented Urnes brooch found in a burial in Viborg is interpreted as a secondary deposition (Seeberg 1961, 13-14, 19; Vellev 1980, 51-52).
8. https://emp-web-94.zetcom.ch/eMP/eMuseumPlus. Föremål nr. 2070, Inv.nr.: 47542.

9. The XRF-analyses were undertaken by Anne Lauritsen, SDU. See ASR 13: K315.

10. DIME id: 58051.

11. E.g. ØFM 142x69, 522x263, 620x19.

12. See notes $23-25$.

13. E.g. ØFM 473x89, 522x225, 620x19.

14. E.g. ØFM 356x4, 442x5, 569x27.

15. DKM 20.949 (DIME id: 10021), HOL 20.482x34, ÅHM 5918 (DIME id: 7257), ÅHM (not yet accessioned in the museum; DIME id: 3516, 10895), VMÅ (DIME id: 10106), FHM 5691 (DIME id: 2051).

16. E.g. VSM 10528x189, ØFM 572x40, 564x41, Dime id: 59495.

17. E.g. VSM 10528, x189, ØFM 142x46, x68, 383x16.

18. ÅHM 2863x38, x1724, HEM 5566x1 (DIME id: 4812), VSM 9000x153, ORM 1614x23.

19. E.g. VSM 10528x187, x190, ROM 2367x1, ØFM 142x2, 404x7, 441x3. DIME: search: Genstandstype: Guds lam fibel-Agnus Dei fibel.

20. E.g. ØFM 142x8, 419x24, 564x40, 573x10, HEM 5083x8, KAM 2007-27 (MVE), (DIME id: 3819).

21. SMS 1161x44/NM D112/2014.

22. VSM 10528x189 (brooch with no pin but with in situ preserved woolen yarn).

23. An enquiry to Viborg Museum in December 2018, for example, elicited information on the finding of 78 Urnes brooches, 52 Agnus Dei brooches and 37 bird-shaped brooches.

24. From north-eastern Fyn there are 77 Urnes brooches, 44 bird-shaped brooches and 57 circular animal brooches (Beck, Christiansen and Henriksen, in press).

25. In 2017, from the Limfjord area 194 Urnes brooches, 110 circular animal brooches including 88 of the Aalborg-group Type and of the 28 Agnus Dei type, plus and 86 birdshaped brooches, were counted (Trier 2017, 85, tab. 4.4). 


\section{Abbreviations}

ASR: Den antikvariske Samling (now SJM)

DIME: Digitale metaldetektorfund

https://www.metaldetektorfund.dk

DKM: De Kulturhistoriske Museer i Holstebro

Kommune

HAM: Museum Sønderjylland

HEM: Museum Midtjylland

HOL: Holstebro Museum

KAM: Kalundborg Museum

LFS: Museum Lolland Falster

MLF: Museum Lolland Falster

MVE: Museum Vestsjælland
NM: Nationalmuseet

OBM: Odense Bys Museer

ORM: Kroppedal Museum

ROM: Roskilde Museum

SDU: Syddansk Universitet

SJM: Sydvestjyske Museer

SMS: Skive Museum

VHM: Vendsyssel Historiske Museum

VMÅ: Vesthimmerlands Museum

VSM: Viborg Museum

ØFM: Østfyns Museer

ÅHM: Aalborg Historiske Museum

\section{Bibliography}

Andersen, C.B.H., 2015. 'Fugle, drager og lam.' In: C.B.H. Andersen and J. Nielsen, eds. Metaldetektiverne. Detektorfund fra Thy og Mors. Thisted: Museum Thy, 52-55.

Baastrup, M.P., 2007. Vikingetidens og den tidlige middelalders emaljefibler fra Sydvestjylland. By, marsk og geest 19, 5-16.

Baastrup, M.P. and Vang Petersen, P., 2008. Smykkemode. Skalk 2008:3, 8-11.

Baastrup, M.P., 2014. Continental and insular Import in viking Age Denmark: distribution and Circulation. Zeitschrift für Archäologie des Mittelalters, vol. 2013, Nr. 41, 85-207.

Beck, M.R., Christiansen, T.T. and Henriksen, M. B. in press. From Central Space to Urban Place.

Beck, M.R., Christiansen, T.T. and Henriksen, M.B., 2019. Fynske og nordjyske lokaliteter med metalfund 400-1100 e. kr. Katalog. From Central Space to Urban place. Centrum. Forskningscenter for centralitet. Rapport nr. 7. Odense: Odense Bys Museer.

Bergman, K. and Billberg, I., 1976. 'Metallhantverk.' In: A.W. Mårtensson, ed. Uppgrävt förflutet för PKbanken i Lund. Archaeologica Lundensia VII. Lund: Kulturhistoriska Museet i Lund, 199-212.

Bertelsen, L.G., 1992. Præsentation af Ålborggruppen, en gruppe dyrefibler uden dyreslyng. Aarbøger for Nordisk Oldkyndighed og Historie 1991, 237-264.

Bertelsen, L.G., 1993. En dyrefibel i Urnesstil fra Seem. By, marsk og geest 5, 1992, 3-9.

Bertelsen, L.G., 1994. Urnesfibler i Danmark. Aarbøger for nordisk Oldkyndighed og Historie 1992 (1994), 345-370.

Bertelsen, L.G., 2002a. 'Den sene vikingetids kunst.' In: L.G. Bertelsen, ed. Vikingetidens kunst. En udstilling om kunsten $i$ vikingernes verden og efterverden ca. 800-1250. Jelling: Kongernes Jelling, 16-34. 
Bertelsen, L.G., ed. 2002b. Vikingetidens kunst. En udstilling om kunsten i vikingernes verden og efterverden ca. 800-1250. Jelling: Kongernes Jelling.

Blomqvist, R. 1947. Spännen och söljor. Kulturen. En årsbok, 120-155.

Callmer, J., 2003. Wayland. 'An essay on Craft Production i the Early and High Middle Ages in Scandinavia.' In: L. Larson and B. Hårdh, eds. Centrality - Regionality. The social structure of Southern Sweden during the Iron Age. Uppåkrastudier 7. Acta Achaeologica Lundensia Ser. In 8 no. 40. Lund: Almqvist \& Wiksell International, 337-361.

Carelli, P., 2001. En kapitalistisk anda. Kulturelle förandringar i 1100-tallets Danmark. Lund studies in Medieval Archaeology 26. Stockholm: Almqvist \& Wiksell International.

Carelli, P., ed., 2012. Lunds historia - staden och omlandet. 1. Medeltiden. En metropol växer fram. Lund: Lunds Kommun.

Christiansen, T.T., 2017. The productive Limfjord Region in Perspective. A Study of Metal Detecting Sites ads Socioeconomic Development in Denmark, AD 400-1150. PhD thesis. Aarhus: Aarhus Universitetsforlag.

Cinthio, M., 1999. 'Guldsmed i Lund.' In: G. Fellows-Jensen and N. Lund, eds. Beretning fra attende tvarfaglige vikingesymposium. Højbjerg: Hikuin, 35-52.

Dobat, A.S., Christiansen, T.T., Henriksen, M.B., Jensen, P., Laursen, S.V., Jessen, M.D., Ruhe, R., Arntsen, F. and Holst, M.K., 2019. The DIME project - Background, status and future perspectives of a user driven recording scheme for metal detector finds as an example of participatory heritage. Danish Journal of Archaeology 2019, vol. 8, 1-15. https://doi.org/10.7146/dja.v8i0.111422

Feveile, C. and Jensen, S., 2006. Det aldste Ribe. Udgravninger på nordsiden af Ribe Å 1984-2000. Ribe Studier, bd. 1.2. Højbjerg: Jysk Arkæologisk Selskab.

Feveile, C., 2011. Korsfibler af Råhedetypen. En upåagtet fibeltype fra ældre vikingetid. Cruciform fibulas of Råhede type. An overlooked fibula type from the Early viking Age. Kuml 2011, 143-160.

Feveile, C., 2018. 'Nordøstfyn - fra ingen til mange metalrige pladser på få år.' In: V. Hilberg and T. Lemm, eds. Viele Funde - grosse Bedeutung? Potenzial und Aussagewert von Metalldetektorfunden für die siedlungsarchäeologische Forschung der Wikingerzeit. Bericht des 33. Tvarfaglige Vikingesymposiums 9. Mai 2014, Wikinger Museum Haithabu. Schriften des Museums für Archäologie Schloss Gottorf. Ergänzungsreihe. Band 12, 29-48.

Feveile, C., 2017. Ombukkede knivskedebeslag af blik. By, marsk og geest 2017, 50-120.

Gilså, N. in press. Et spørgsmål om stil. Urnesspender i gennembrudt arbejde fra tidlig middelalder. MA-thesis, Aarhus Universitet 2019.

Gotfredsen, L., 2002. 'Den romanske kunst og vikingetidens efterliv.' In: L.G. Bertelsen, ed. Vikingetidens kunst. En udstilling om kunsten i vikingernes verden og efterverden ca. 800-1250. Jelling: Kongernes Jelling, 35-53. 
Gräslund, A., 2006. 'Wolves, serpents, and birds. Their symbolic meaning in Old Norse belief.' In: A. Andrén, K. Jennbert and C. Raudvere, eds. Old Norse religion in long-term perspective. An international conference in Lund, Sweden, June 3-7, 2004. Lund: Nordic Academic Press, 124-129.

Hedegaard, K.R., 1992. Bronzestøberhåndværket i yngre germanertid og tidlig vikingetid i Skandinavien - teknologi og organisation. Lag 1992, 75-92.

Henriksen, M.B., 2017. 'Odenses naboer - metalrige bopladser vest og øst for Odense Fjord.' In: M. Runge and J. Hansen, eds. Knuds Odense - Vikingernes by. Odense: Odense Bys Museer, 25-34 and catalogue.

Hårdh, B., 2010. 'Viking age Uppåkra. Från romartida skalpeller till senvikingatidiga urnesspännen. Nya materialstudier från Uppåkra.' In: B. Hårdh, ed. Uppåkrastudier 11 Lund: Institutionen för Arkeologi och Antikens Historia, 247-316.

Jensen, C.V., 2018. På sporet af kongens møntsmedje i 1000-tallets Aalborg. Årbog 2017. Nordjyllands Historiske Museum, 51-57.

Jensen, J.S., Bendixen, K., Liebgott, N.-K. and Lindahl, F., 1992. Danmarks middelalderlige skattefund c. 1050-1550. Bd. I. København: Det Kongelige Nordiske Oldskriftselskab.

Jensen, J.S., ed., 1995. Tusindtallets Danske Mønter fra Den kongelige Mønt-og Medaillesamling. Danish coins from the $11^{\text {th }}$ century in the Royal Collection of Coins and Medals. København: Nationalmuseet.

Jensen, S., 1991. Metalfund fra vikingetidsgårdene ved Gl. Hviding og Vilslev. By, marsk og geest 3. Årsberetning 1990. Den antikvariske Samling i Ribe, 27-40.

Jouttijärvi, A., Thomsen, T. and Moltsen, A.S.A., 2005. 'Værkstedets funktion'. In: M. Iversen, D.E. Robinson, J. Hjermind and C. Christensen, eds. Viborg Søndersø 1018-1030. Arkaologi og naturvidenskab i et varkstedsområde fra vikingetid. Viborg: Jysk Arkæologisk Selskab, 297-320.

Karlsson, L., 1981. 'Sløjfemotivet i Sverige under missionsskedet.' In: J. Vellev, ed. Romanske stenarbejder 1. Højbjerg: Hikuin, 91-118.

Kock, J. 1992. Håndværksnæringen. Aalborgs Historie 1. Fra Aalborgs fodsel til Grevens Fejde 1534. Aalborg: Aalborg Kommune, 339-347.

Kristensen, T.R., 1999. 'Metal.' In: P.K. Madsen, ed. Middelalderkeramik fra Ribe. Byarkaologiske undersøgelser 1980-87. Højbjerg: Jysk Arkæologisk Forlag/Aarhus Universitetsforlag, 132-144.

Kristensen, H.K. and Poulsen, B. 2016. Danmarks byer i middelalderen. Aarhus: Aarhus Universitetsforlag.

Lindahl, F., 1983. Roskildedyret - en dyreslyngsfibula. Historisk Årbog fra Roskilde Amt 1982, 37-43.

Lønborg, B., 1994. Masseproduktion af Urnesfibler! Aarbøger for nordisk Oldkyndighed og Historie 1992 (1994), 371-378. 
Lønborg, B., 1998. Vikingetidens metalbearbejdning. Odense University Studies in history and Social Sciences vol. 203. Fynske Studier 17.

Madsen, H.B., 1984. 'Metalcasting.' In: M. Bencard, ed. Ribe Excavations 1970-76. Vol. 2. Esbjerg: Sydjysk Universitetsforlag, 15-189.

Pedersen, A., 2001. Rovfugle eller duer. Fugleformede fibler fra den tidlige middelalder. Aarbøger for Nordisk Oldkyndighed og Historie 1999 (2001), 19-66.

Pedersen, A., 2004. 'Religiøse symboler i vikingetidens arkæologiske materiale.' In: N. Lund, ed. Kristendommen i Danmark for 1050. Et symposium i Roskilde. Roskilde: Roskilde Museums forlag, 60-74.

Pedersen, A., 2010. 'Unika og masseproduktion.' In: M. Andersen and P.O. Nielsen, eds. Danefa. Skatte fra den danske muld. Til Hendes Majestat Dronning Margrethe 2. København: Gyldendahl, 206-209.

Pedersen, A., 2014. 'Late Viking and Early Medieval Ornaments.' In: I. Garipzanov, ed. A question of faith. Conversion and Identity in the Viking Age. Turnhout: Brepols Publishers, 195-224. https://doi.org/10.1484/M.MISCS-EB.1.102038

Pedersen, P., 1981. 'Orm og strop.' In: J. Vellev, ed. Romanske stenarbejder 1. Højbjerg: Hikuin, 69-90.

Pedersen, U., 2016. Into the melting pot. Non-ferrous Metalworkers in Viking-period Kaupang. Kaupang Excavation Project. Publication Series, Volume 4. Norske Oldfunn XXV. Aarhus: Aarhus University press.

Petersen, P.V., 2005. 'Odins fugle, valkyrier og bersærker - billeder fra nordisk mytologi fundet med metaldetektor.' In: K.M. Boe, ed. Ragnarok. Odins verden. Silkeborg: Silkeborg Museum, 57-86.

Ramskou, T., 1957. Lindholm Høje. Third preliminary Report for the Years 1956-1957 on the excavation of a Late Iron Age Cemetary and an Early Medieval Settlement. Acta Archaeologica Vol. XXVIII, 193-203.

Riismøller, P. 1960. Nålemageren fra Strandstien. Kuml 1960, 117-131.

Roesdahl, E., 2004. 'Hvornår blev kirkene bygget?' In: N. Lund, ed. Kristendommen i Danmark for 1050. et symposium i Roskilde den 5-7 februar 2003. Roskilde: Roskilde Museums forlag, 201-206.

Roslund, M., 2010. Västanfläkt eller en stadig vind? Kontinentala och insulåara inslag i Sigtunas tidiga medeltid. Situne Dei. Arsskrift för Sigtunaforskning, 43-52.

Røstad, I.M., 2012. En fremmed fugl: "Danske” smykker og forbindelser på Østlandet i overgangen mellem vikingetid og middelalder. Viking. Norsk arkeologisk årbok LXXV 2012, 181-210.

Salminen, L. and Hervén, C.J., 2001. 'Bronshantverket i brytningstid - exemplet Lund.' In: B. Hårdh, ed, Uppåkra. Centrum och sammanhang. Uppakrastudier 3. Archaeologica Lundensia. Series in 8o, No. 34. Lund: Almqvist \& Wiksell International, 259-274.

Seeberg, P., 1961. En navnløs kirke i Viborg. Fra Viborg amt. Arbog udgivet af Historisk Samfund for Viborg Amt. 29. årgang. Viborg, 10-20. 
Staecker, J., 1999. Rex Regnum et dominus dominorum. Die wikingerzeitlichen Kreuz-und Kruzifixanhänger als Ausdruck der Mission in Altdänemark und Schweden. Lund Studies in Medieval Archaeology 23. Stockholm: Lund: Almqvist \& Wiksell International.

Stenholm, L., 1976. 'Dräkttillbehör och smycken.' In: A.W. Mårtensson, ed. Uppgrävt förflutet för PKbanken i Lund. Archaeologica Lundensia VII. Lund: Kulturhistoriska Museet i Lund, 293-305.

Söderberg, A., 2004. Metallurgic ceramics as a key to Viking Age workshop organisation. Journal of Nordic Archaeological Science 14, 2004, 115-124.

Söderberg, A., 2018. Viking Jewellery Mould Making. Experimental and Reconstructive Aspects. EXARC.net. Issue 2018/4, 1-12.

Søvsø, M.H. and Knudsen, M., 2019. Religiøst liv i det middelalderlige Ribe - belyst ud fra genstandsfund fra byen og dens opland. Aarbøger for nordisk Oldkyndighed og Historie 2016, 119-154.

Thomsen, T., 2005. 'Udgravningen - en kronologisk gennemgang af de fysiske spor.' In: M. Iversen, D.E. Robinson, J. Hjermind and C. Christensen, eds. Viborg Søndersø 1018-1030. Arkeologi og naturvidenskab i et varkstedsområde fra vikingetid. Højbjerg: Jysk Arkæologisk Selskab, 61-82.

Vellev, J., 1980. Vikingetidens kunst i Viborg, MIV 10. 44-59.

Vellev, J., 1981. 'Sløjfeportalerne omkring Randers.' In: J. Vellev, ed. Romanske stenarbejder 1. Højbjerg: Hikuin, 9-68.

Wahlöö, C., 1976. 'Lagerbild och fasindelning.' In: A.W. Mårtensson, ed. Uppgrävt förflutet för PKbanken i Lund. Archaeologica Lundensia VII. Lund: Lund: Almqvist \& Wiksell International, 15-20.

Wood, R., 2014. The pictures on the greater Jelling stone. Journal of Danish archaeology 2014. Volume 3, issues 1+2, 19-32. https://doi.org/10.1080/21662282.2014.929882 